\title{
Sedimentary oxygen dynamics in a seasonally hypoxic basin
}

\author{
Dorina Seitaj, ${ }_{1}^{1 *}$ Fatimah Sulu-Gambari, ${ }^{2}$ Laurine D. W. Burdorf, ${ }^{1}$ Alicia Romero-Ramirez, ${ }^{3}$ \\ Olivier Maire, ${ }^{3}$ Sairah Y. Malkin, ${ }^{4,5}$ Caroline P. Slomp, ${ }^{2}$ Filip J. R. Meysman ${ }^{1,4}$ \\ ${ }^{1}$ Department of Ecosystem Studies, Royal Netherlands Institute for Sea Research (NIOZ), Yerseke, \\ The Netherlands \\ ${ }^{2}$ Earth Sciences (Geochemistry), Faculty of Geosciences, Utrecht University, Utrecht, \\ The Netherlands \\ ${ }^{3}$ University of Bordeaux, CNRS, EPOC, UMR 5805, Talence, France \\ ${ }^{4}$ Department of Analytical, Environmental and Geochemistry, Vrije Universiteit Brussel (VUB), \\ Brussels, Belgium \\ ${ }^{5}$ Horn Point Laboratory, University of Maryland Center for Environmental Science (UMCES), Cambridge, Maryland
}

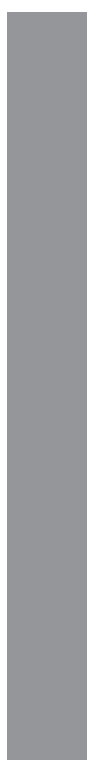

\begin{abstract}
Seasonal hypoxia refers to the oxygen depletion that occurs in summer in the bottom water of stratified systems, and is increasingly observed in coastal areas worldwide. The process induces a seasonal cycle on the biogeochemistry of the underlying sediments, which remains poorly quantified. Here, we investigated the sedimentary oxygen consumption within Lake Grevelingen (The Netherlands), a saline coastal reservoir that is impacted by yearly recurrent bottom water hypoxia. Monthly sampling campaigns were conducted throughout 2012 at three sites along a depth gradient. Macrofauna sampling and sediment profile imaging demonstrated how summer hypoxia strongly impacts the benthic communities below $15 \mathrm{~m}$ of water depth. Benthic fluxes of oxygen, dissolved inorganic carbon, total alkalinity, and ammonium were determined by closed core incubations, while oxygen depth profiles were recorded by microsensor profiling of sediment cores. Our results reveal a pronounced seasonality in the sedimentary oxygen consumption. Low uptake rates in summer were caused by oxygen limitation, and resulted in the build-up of an "oxygen debt" through the accumulation of reduced iron sulfides. Highest oxygen uptake rates were recorded in fall, linked to the reoxidation of the pool of iron sulfides in the top layer. However, uptake rates remained unexpectedly high during winter and early spring, likely associated with the oxidation of iron sulfides down to centimeters depth due to the electrogenic sulfur oxidation by cable bacteria. Overall, our results suggest that the sedimentary oxygen dynamic in seasonally hypoxic coastal systems is characterized by a strongly amplified "oxygen debt" dynamics induced by cable bacteria.
\end{abstract}

Semi-enclosed and stratified coastal areas can experience a yearly pattern of oxygen depletion in their bottom waters, a phenomenon that is referred to as seasonal hypoxia (Diaz 2001; Middelburg and Levin 2009). The observed increase of the duration, and intensity of seasonal hypoxia (defined as $\mathrm{O}_{2}<63 \mu \mathrm{mol} \mathrm{L}{ }^{-1}$ ) in the coastal ocean is recognized as an environmental problem of worldwide concern (Diaz and Rosenberg 2008). The phenomenon is primarily linked to the anthropogenic input of nutrients (Conley et al. 2009), which enhances primary production and export of organic matter from surface waters, thus resulting in increased

*Correspondence: dorina.seitaj@nioz.nl

Additional Supporting Information may be found in the online version of this article. microbial respiration and oxygen consumption in the bottom water (Rabalais et al. 2002; Kemp et al. 2005; Conley et al. 2009). At the same time, climate change is anticipated to increase the temperature of the surface waters in summer, and the resulting intensification of water column stratification and decrease in oxygen solubility may exacerbate coastal hypoxia in the upcoming decades (Meire et al. 2013).

Seasonal hypoxia has profound effects on the biogeochemical cycling (Turner et al. 2008; Conley et al. 2009; Kemp et al. 2009; Middelburg and Levin 2009; Rabalais et al. 2010; Testa and Kemp 2011) and on the survival and behavior of marine organisms in coastal systems (Diaz and Rosenberg 1995; Rosenberg et al. 2002; Vaquer-Sunyer and Duarte 2008; Levin et al. 2009). Benthic faunal communities inhabiting seasonally hypoxic areas typically exhibit low diversity and abundance, as well as limited sediment reworking 
activity (Diaz and Rosenberg 1995; Levin et al. 2009). A reduced faunal activity may result in a higher accumulation of reduced compounds and a reduced remineralization and an increased burial of organic matter (Berner and Westrich 1985; Middelburg and Levin 2009).

The oxygen depletion in the bottom waters of stratified systems is ultimately caused by an imbalance between the oxygen supply from surface waters (resulting from atmospheric input and primary production in the photic zone), and the removal of oxygen within the bottom waters (Testa and Kemp 2011). Sediments can account for up to $80 \%$ of the total oxygen consumption in shallow coastal systems (Middelburg and Levin 2009), and hence, the sediment likely forms an important sink of oxygen in seasonally hypoxic basins, as has been previously demonstrated for freshwater lakes (Cornett and Rigler 1987; Pace and Prairie 2005).

The close coupling between benthic and pelagic compartments is a fundamental feature of shallow coastal ecosystems, and the geochemical cycling in sediments is crucial in regulating this benthic-pelagic exchange (Soetaert and Middelburg 2009). Seasonal patterns in sedimentary oxygen consumption and benthic mineralization are often complex, and affected by simultaneous and interdependent processes (Glud 2008). Seasonality in benthic mineralization, and consequently in sedimentary oxygen consumption, may result from a variety of factors, such as variations in bottom water temperature (Thamdrup et al. 1998), organic matter input to the sediment (Canfield et al. 1993), and bottom water oxygen concentration (Cai and Reimers 1995) as well as seasonality in the activity and abundance of benthic fauna (Aller 1988). Another factor affecting the seasonality in oxygen uptake is the socalled "oxygen debt" (Pamatmat 1971), which represents the oxygen required to re-oxidize reduced compounds (defined as oxygen demand units [ODUs]; Soetaert et al. 1996) that have accumulated in the sediment during previous months (typically summer). In seasonally hypoxic systems, the fulfillment of the oxygen debt occurs mainly in fall via the oxidation of ODUs, that have accumulated in the sediment throughout summer (Martens and Klump 1984; Chanton et al. 1987; Boynton et al. 1990; Rasmussen and Jorgensen 1992; Moeslund et al. 1994; Brady et al. 2013).

The formation of an "oxygen debt" has been principally linked to the transient accumulation of iron sulfides (FeS) in surficial coastal sediments (Jørgensen 1977). These reduced sulfur compounds can be further transformed to pyrite and become buried (Berner 1970), or undergo oxidation on contact with oxygen (Luther et al. 1982; Thamdrup et al. 1994). In some coastal sediments, the reoxidation of iron sulfides can account for up to one third of the sedimentary oxygen consumption (Jørgensen 1996), hence, iron sulfide reoxidation represents a major oxygen sink (Glud 2008). Recently, it has been shown that the iron sulfide reservoir can exhibit a marked seasonality in sediments of seasonally hypoxic basins
(Seitaj et al. 2015; Sulu-Gambari et al. 2016). This seasonal variation was attributed to the metabolic activity of cable bacteria (Seitaj et al. 2015; Sulu-Gambari et al. 2016). These filamentous bacteria, which induce long-distance electron transport in the sediment (Nielsen et al. 2010), are thought to be widespread in the sediments of seasonally hypoxic systems (Malkin et al. 2014), and their metabolism has been shown to exert a powerful impact on the sediment geochemistry (Risgaard-Petersen et al. 2012; Rao et al., 2016). However, the impact of cable bacteria metabolism on the sedimentary oxygen dynamics in seasonally hypoxic basins remains to be determined.

The principal research objective here was to document the sedimentary oxygen dynamics in a seasonally hypoxic environment. Building on two studies examining the microbiology and geochemistry of the sediment within Lake Grevelingen (The Netherlands) (Seitaj et al. 2015; Sulu-Gambari et al. 2016), our study was conducted within the same seasonally hypoxic basin. To determine the drivers of the seasonality in the sedimentary oxygen consumption, we investigated both the bottom water chemistry and sediment geochemistry at three stations along a depth gradient within the zone affected by hypoxia. Benthic fluxes of oxygen $\left(\mathrm{O}_{2}\right)$, dissolved inorganic carbon (DIC), ammonium $\left(\mathrm{NH}_{4}^{+}\right)$, and total alkalinity (TA) were determined in closed chamber incubations, and microsensor profiling was used to quantify the diffusive oxygen uptake (DOU). Sediment profile images (SPIs) and benthic macrofauna data were collected in relation to oxygen conditions in the water column. By combining all measurements, we documented the seasonal variations of the sedimentary oxygen consumption and assessed the role of cable bacteria in these dynamics.

\section{Materials and methods}

\section{Study site and sampling procedure}

Lake Grevelingen is a former estuary within the ScheldtMeuse-Rhine delta area of The Netherlands (Fig. 1a,b), which has been closed off by dams at the landward side and seaward side since 1971. Lake Grevelingen (surface area $115 \mathrm{~km}^{2}$ ) consists mostly of shallow water areas less than $12.5 \mathrm{~m}$ water depth, but in the former estuarine channels, deeper basins are found, which extend down to $45 \mathrm{~m}$ water depth. These deeper basins are separated from each other by sills. A sluice on the seaward side enables a limited exchange of water with the open North Sea. Hagens et al. (2015) estimated that the inflow from the North Sea could replenish the water in the entire basin in $30 \mathrm{~d}$. Due to the exchange with the North Sea, the LG waters approach coastal salinity values (range 29-32). Due to the absence of both tides and strong currents, the water column becomes stratified each summer, thus leading to seasonal hypoxia $\left(\mathrm{O}_{2}<63\right.$

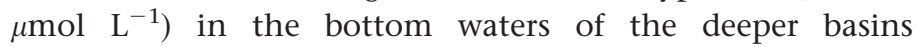
(Wetsteyn 2011; Fig. 1c). 
(a) North Sea
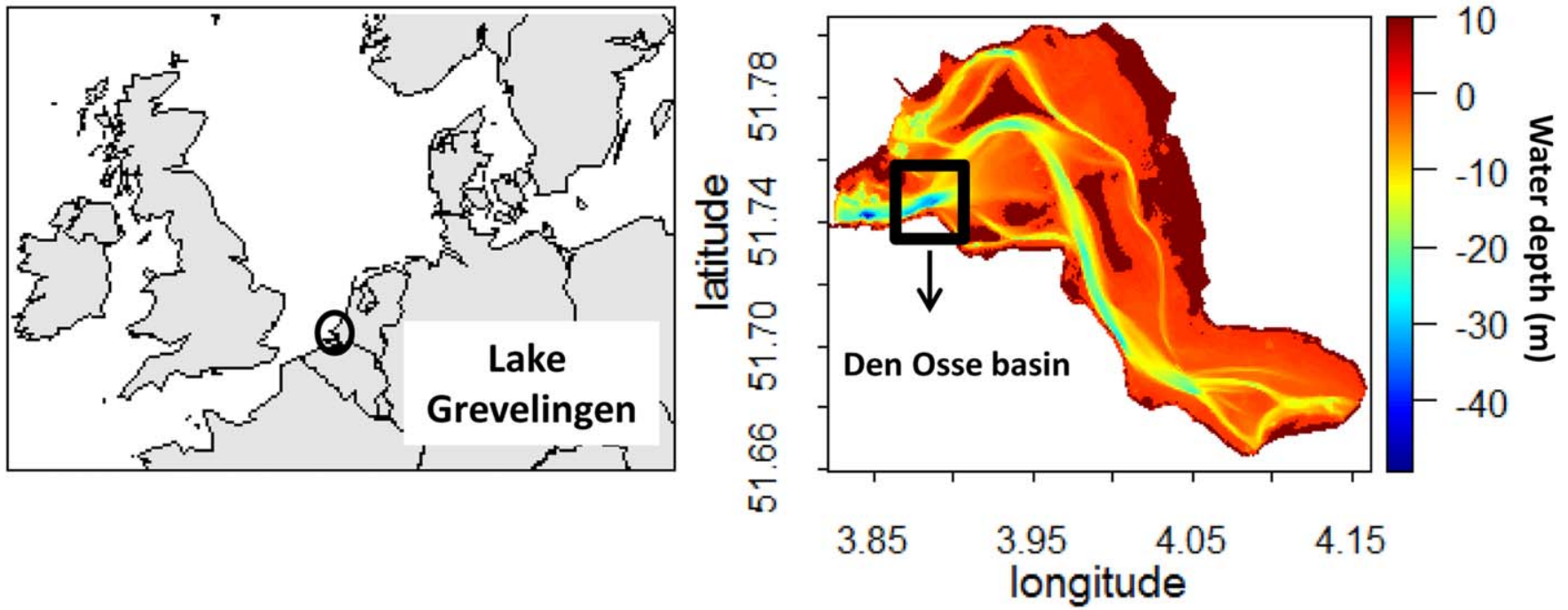

\section{(b) Bathymetry Lake Grevelingen}

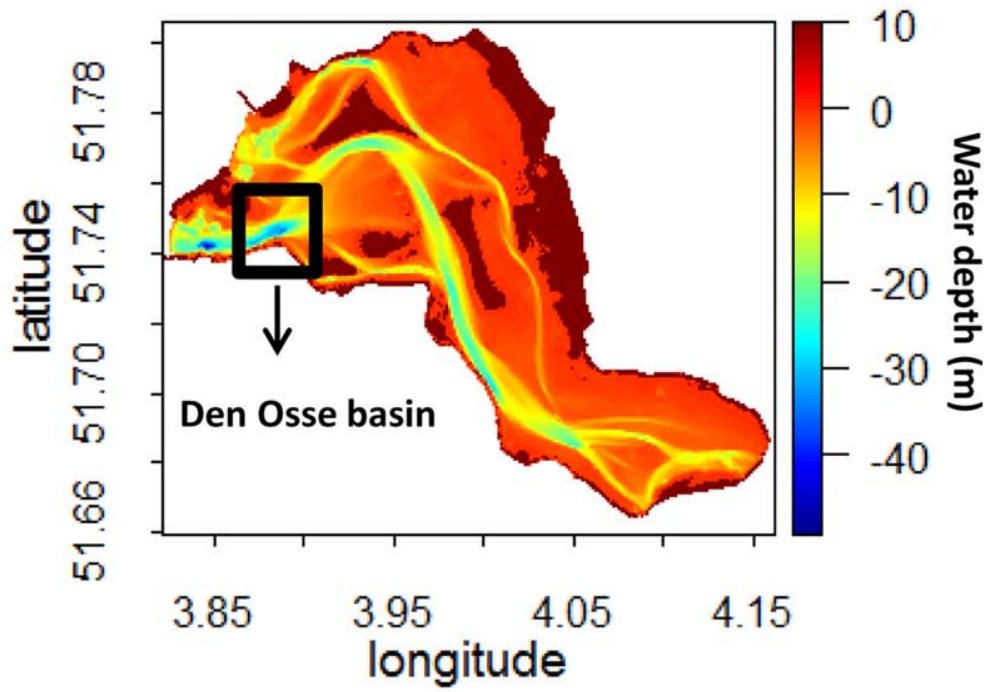

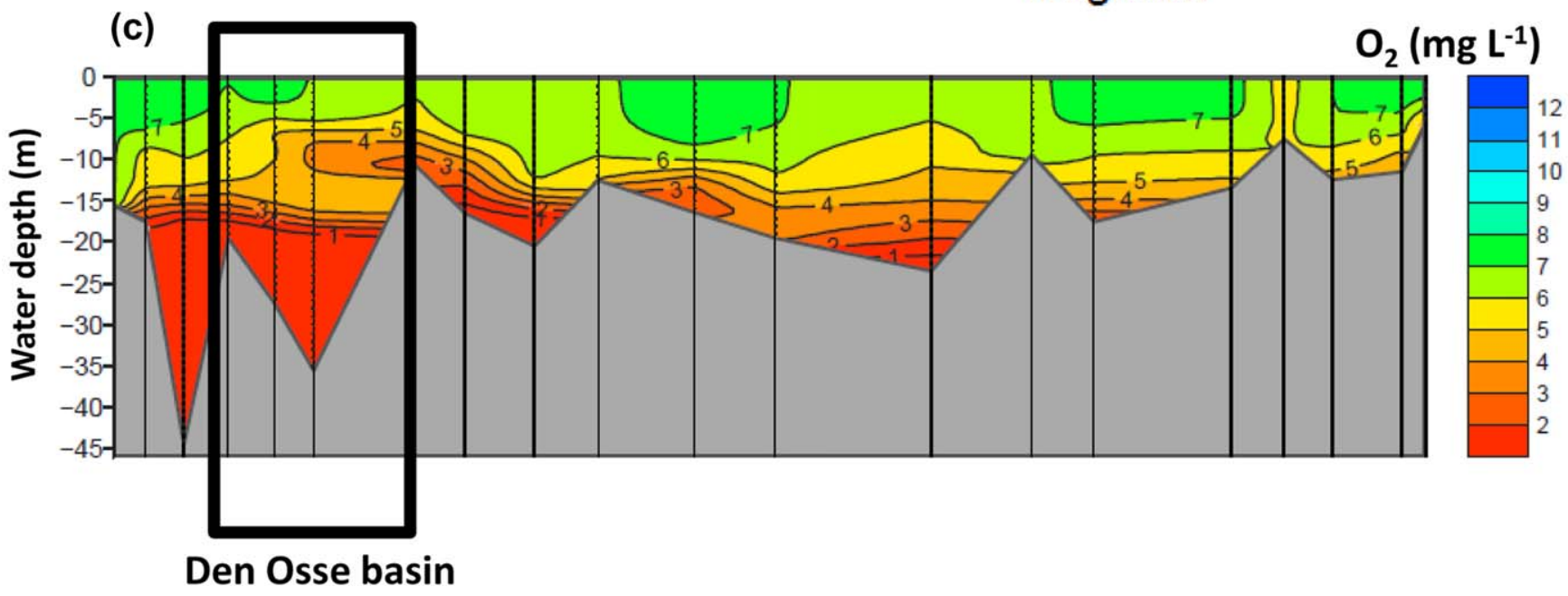

Fig. 1. (a) Map of the Southern North Sea; (b) bathymetry of Lake Grevelingen (deepest site $34-\mathrm{m}$ depth: $\mathrm{S} 1 ; 51.747^{\circ} \mathrm{N}$. $\left.3.890^{\circ} \mathrm{E}\right) ;(\mathbf{c})$ depth-map showing the oxygen concentrations in the water column in August 2012 (data from the executive arm of the Dutch Ministry of Infrastructure and the Environment). The black rectangle indicates the area of the Den Osse basin, object of investigation in this study.

During 2012, we performed monthly sampling campaigns on board of the $\mathrm{R} / \mathrm{V}$ Luctor, examining both the watercolumn chemistry and sediment biogeochemistry. Sampling took place in the Den Osse basin, which is located in the western (seaward) part of Lake Grevelingen (Fig. 1c). This basin has a maximum water depth of $34 \mathrm{~m}$, and is enclosed by sills at the landward $(10 \mathrm{~m})$ and seaward side $(20 \mathrm{~m})$. Sediment sampling was performed at three stations along a depth gradient within the basin: S1was located in the deepest point of the basin at $34 \mathrm{~m}$ water depth $\left(51.747^{\circ} \mathrm{N}\right.$, $\left.3.890^{\circ} \mathrm{E}\right), \mathrm{S} 2$ at $23 \mathrm{~m}\left(51.749^{\circ} \mathrm{N}, 3.897^{\circ} \mathrm{E}\right)$, and $\mathrm{S} 3$ at $17 \mathrm{~m}$ $\left(51.747^{\circ} \mathrm{N}, 3.898^{\circ} \mathrm{E}\right)$. Intact sediment cores were retrieved with a single core gravity corer (UWITEC, Austria) using PVC core liners (6 $\mathrm{cm}$ inner diameter, $60 \mathrm{~cm}$ length). All cores were inspected on retrieval and only visually undisturbed sediment cores were used for further analysis.

Water-column sampling was performed at Sta. S1. The three Sta. S1-S3 were located within around $500 \mathrm{~m}$ of each other, and available water quality monitoring data (Wetsteyn, 2011; Fig. 1c) show that the water column is laterally homogenous over such short distances (Fig. 1). Accordingly, the bottom water parameters at Sta. S2 and S3 were derived from the corresponding water depths at S1. A CTD instrument (YSI 6600) was deployed to record the depth profiles of temperature $(T)$, salinity $(S)$, pressure $(P)$, and oxygen concentration. The stratification parameter $\sigma\left(\mathrm{J} \mathrm{m}^{-3}\right)$ represents the amount of energy required to fully homogenize the water column through vertical mixing (Simpson 1981), 
and was calculated from the CTD data as (Hagens et al. 2015):

$$
\sigma=\frac{1}{H} \int_{H}^{0}\left(\rho-\rho_{\mathrm{w}}\right) g z d z \text { where } \rho=\frac{1}{H} \rho_{\mathrm{w}} z d z
$$

Here, $H$ is the total height of the water column $(\mathrm{m}), z$ is depth (m), $g$ is gravitational acceleration $\left(\mathrm{m} \mathrm{s}^{-2}\right.$ ), and $\rho_{\mathrm{w}}$ denotes the water density $\left(\mathrm{kg} \mathrm{m}^{-3}\right)$, calculated from $T, S$, and $P$ according to Feistel (2008) using the R package CRAN: AquaEnv.

In addition to the CTD profiling, discrete bottom water samples were collected at $2 \mathrm{~m}$ above the sediment surface at S1 with a 12 liter Niskin bottle to assess the concentrations of oxygen $\left(\mathrm{O}_{2}\right)$, DIC, TA, and ammonium $\left(\mathrm{NH}_{4}^{+}\right)$. In summer, the Niskin bottle was held stationary in the bottom water for at least $10 \mathrm{~min}$ before retrieval, to allow complete flushing of the Niskin bottle and hence enable an unbiased sampling of the low-oxygen bottom water. Water samples were drawn from the Niskin bottle using Tygon tubing to avoid gas exchange with the surrounding atmosphere.

\section{Sediment incubations}

Shipboard closed core incubations were performed to determine the fluxes of $\mathrm{O}_{2}, \mathrm{DIC}, \mathrm{TA}$, and $\mathrm{NH}_{4}^{+}$across the sediment-water interface. Incubations were performed in the dark and in triplicate, using intact sediment cores taken by the gravity corer. On collection, these sediment cores were of variable height, and to obtain comparable flux results, the water level was adjusted to a fixed level of $18-20 \mathrm{~cm}$ above the sediment surface by carefully pushing the sediment upwards in the core liner via the insertion of inert polyurethane disks from below. The core incubations were started within $30 \mathrm{~min}$ after sediment collection. To ensure that the boundary conditions at the sediment-water interface closely resembled in situ conditions, the overlying water was replaced with bottom water (collected with the Niskin bottle as described above) prior to the start of the incubations. This water replacement was executed via a Tygon tubing, and during the procedure, a floating plastic sheet was placed inside the core, to avoid sediment resuspension and disturbance of the sediment-water interface during water replacement. Immediately thereafter, the cores were sealed with gas-tight polyoxymethylene lids and transferred to a temperature controlled incubator (LT650; Elbanton) operating at the in situ bottom water temperature. The core lids contained a central stirrer to ensure the overlying water remained well mixed, as well as two sampling ports to enable discrete water subsampling. The incubation time was determined such that the change in oxygen concentration $\left[\mathrm{O}_{2}\right]$ would remain nearly linear during the incubation. Under oxic bottom water conditions, we allowed $\left[\mathrm{O}_{2}\right]$ to maximally decrease to $50 \%$ air saturation, whereas during the hypoxic period, we ensured that the waters would not become anoxic and $\left[\mathrm{O}_{2}\right]$ remained above 5\% air saturation.
As a result, incubation times varied between stations and sampling campaigns, from $6 \mathrm{~h}$ at S1 during summer, up to $65 \mathrm{~h}$ at $\mathrm{S} 3$ during winter.

The total oxygen uptake (TOU) of the sediment was determined by following the decrease of the $\mathrm{O}_{2}$ concentration non-invasively in the overlying water of the closed cores, using Oxygen Spot Sensors (OXSP5; Pyroscience), which were attached to the inner wall of each core liner. The optode signal was read out by an Optical Fiber (SPFIB; Pyroscience) connected to the outer wall of the core liner for the entire duration of the incubation, using a Basic Spot Adapter (SPADBAS; Pyroscience) and a Lens Spot Adapter (SPADLNS; Pyroscience). This procedure enabled a continuous (30 sec interval) measurement of the oxygen concentration in the overlying water, avoiding the gas bubble intrusion that often accompanies the insertion of sensors into chamber incubations. A temperature sensor (TSUB21; Pyroscience) was placed inside the incubator near the cores, to continuously monitor the incubation temperature. The four oxygen sensors and the temperature sensor were connected to a FireStingO2 oxygen meter (Pyroscience), located outside the incubator. Prior to sediment sampling, the Oxygen Spots were calibrated via a two-point calibration at $0 \% \mathrm{O}_{2}$ saturation (saturated $\mathrm{Na}_{2} \mathrm{SO}_{3}$ solution) and $100 \% \mathrm{O}_{2}$ saturation (artificial seawater bubbled with air at in situ temperature and salinity).

To monitor the DIC and $\mathrm{NH}_{4}^{+}$change in the overlying water of the incubations, water samples were collected at regular time intervals (5 times). Samples were withdrawn using a syringe via one sampling port, and concurrently, an equal amount of ambient bottom water was added through a replacement syringe attached to the other sampling port. DIC samples $(\sim 7 \mathrm{~mL})$ were withdrawn using a glass syringe, and a subsample was transferred to a headspace vial, poisoned with $5 \mu \mathrm{L} \mathrm{HgCl}_{2}$ and stored submerged at $4^{\circ} \mathrm{C}$. Samples for $\mathrm{NH}_{4}^{+}(\sim 3 \mathrm{~mL})$ were collected using a plastic syringe, and afterwards were filtered $(0.45 \mu \mathrm{m}$ Millex-HA syringe filter) and stored in the dark at $4^{\circ} \mathrm{C}$. Non-filtered water samples for TA $(\sim 10 \mathrm{~mL})$ were collected in $25 \mathrm{~mL}$ centrifuge tubes only at the beginning and end of the incubation, and stored in the dark at $4^{\circ} \mathrm{C}$. Each subsampling total volume of $10 \mathrm{~mL}$ was less than $5 \%$ of the water mass, so no correction factor was applied to account for dilution.

The TOU, DIC, TA, and $\mathrm{NH}_{4}^{+}$fluxes $\left(\mathrm{mmol} \mathrm{m} \mathrm{m}^{-2} \mathrm{~d}^{-1}\right)$ were calculated from the concentration change in the overlying water $\Delta C_{\text {ow }}$ over the time period $\Delta t$, taking into account the enclosed sediment area A and the overlying water volume $V_{\text {ow: }}$ :

$$
J=\left(\frac{\Delta C_{\mathrm{ow}}}{\Delta t}\right) \frac{V_{\mathrm{ow}}}{A}
$$

In all months, the oxygen concentration change $\left(\Delta C_{\text {ow }} / \Delta t\right)$ was determined by linear regression as the initial slope (i.e., 
the part when the oxygen decrease remained linear) of the recorded oxygen time series. Similarly, in March, May, August, and November the DIC and $\mathrm{NH}_{4}^{+}$concentration changes were calculated from the five data points by linear regression. In the remaining months, no subsampling was performed, but fluxes were calculated from the concentration difference between start and end of the incubation. DIC fluxes were determined in March, and then monthly from May onwards. TA flux measurements were performed in March, May, August, and November, and the flux was calculated from the concentration change in the overlying water between start and end of the incubation.

\section{Analytical methods}

DIC was determined using an AS-C3 DIC analyzer (Apollo SciTEch), in which a sample is acidified and the released $\mathrm{CO}_{2}$ detected using a solid state infra-red $\mathrm{CO}_{2}$ detector (Licor LI 7000). Three replicate measurements were carried out for each sample analyzed. All DIC measurements were calibrated using Certified Reference Material (CRM Batch 116 - accura-

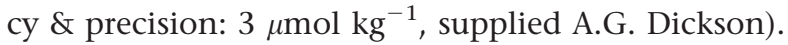

TA was determined using the standard operating procedure for open cell potentiometric titration, using an automatic titrator (Metrohm 888 Titrando), and a combined Metrohm glass electrode (Unitrode) following the procedure SOP3a as described in Dickson et al. (2007). Concentrations of $\mathrm{NH}_{4}^{+}$were determined by automated colorimetric techniques using a Seal QuAAtro autoanalyzer.

\section{Microsensor profiling}

Oxygen depth profiles were recorded by microsensor profiling using commercial $\mathrm{O}_{2}$ micro-electrodes with 25- or 50$\mu \mathrm{m}$ tips (Unisense A.S., Denmark), a Multimeter amplifier system (Unisense A.S., Denmark) and a motorized micromanipulator (Unisense A.S., Denmark). The microsensor profiling was always started within $2 \mathrm{~h}$ of core collection, Measurements took place in the dark, in a thermo-regulated room, which was set to the temperature of in situ bottom water. To enable profiling in the core liner, the sediment was first pushed upwards until $\sim 10 \mathrm{~cm}$ of overlying water remained (procedure as detailed above). During profiling, the overlying water was gently stirred using a custom-made propeller to ensure the establishment of a suitable diffusive boundary layer (DBL). Oxygen depth profiles were recorded at $50 \mu \mathrm{m}$ resolution. Micro-electrodes were calibrated using a 2-point calibration made in air-saturated seawater (100\%) and the anoxic zone of the sediment (0\%). A single depth profile was collected in three replicate cores at each of the three stations during each monthly sampling campaign. The DOU was calculated from the oxygen depth profiles using Fick's first law:

$$
\mathrm{DOU}=-\frac{\phi}{(1-2 \ln \phi)} D_{\mathrm{O}_{2}} \frac{d\left[\mathrm{O}_{2}\right]}{d x}
$$

where $x$ represents the depth into the sediment and, $\phi$ denotes the porosity, and the term $(1-2 \ln \phi)$ is a correction for sediment tortuosity (Boudreau 1996). The concentration gradient $d\left[\mathrm{O}_{2}\right] / d x$ was calculated via linear regression as the slope of the $\mathrm{O}_{2}$ depth profile just below the sediment-water interface. Depending on the thickness of the oxic sediment layer, between 4 and 12 data points were included in the regression. The diffusion coefficient $D_{\mathrm{O}_{2}}$ was calculated from salinity $(S)$ and temperature $(T)$ using the R package CRAN: marelac (Soetaert et al. 2010).

\section{Sediment parameters}

Porosity was determined at $2 \mathrm{~mm}$ resolution over the first $40 \mathrm{~mm}$, in one sediment core collected at each site in March, May, August, and November. Sediment layers were collected via slicing, with the exception of August, when a syringe and a plexiglass ring (2-mm thick) were used to withdraw the first 2-mm layer, due to the high fluffiness of the upper sediment layer. Porosity was calculated from water content and solid phase density measurements. Water content was determined by drying sediment samples to a constant weight at $60^{\circ} \mathrm{C}$ accounting for the salt content of the pore water. The solid phase density was obtained from the volume displacement after adding a known mass of dry sediment to a graduated cylinder. The sediment grain size distribution was determined by laser diffraction using a Malvern Mastersizer 2000 (McCave et al. 1986). Different horizons within the top sediment showed a distinct coloration, and the thickness and color type of these layers were recorded directlyafter core collection. Furthermore, a custom-made plexiglass device was used to longitudinally cut and remove one half of the top $20 \mathrm{~cm}$ of a sediment core, so that the mid-plane section was exposed and could be photographed.

For organic carbon and nitrogen analysis, one sediment core per site was sliced at $0.5 \mathrm{~cm}$ resolution over $10 \mathrm{~cm}$ in a $\mathrm{N}_{2}$-purged glove-bag in March, May, August, and November. Sediment samples were freeze-dried and ground to a fine powder. A $0.3 \mathrm{~g}$ subsample was acidified with $1 \mathrm{M} \mathrm{HCl}$ to remove inorganic carbon (Van Santvoort et al. 2002) and then analyzed to determine organic carbon $\left(\mathrm{C}_{\text {org }}\right)$ and organic nitrogen $\left(\mathrm{N}_{\text {org }}\right)$ (\% dry weight; Fison Instruments, NA 1500 NCS element analyzer). A second subsample $(0.1 \mathrm{~g})$ of freeze-dried, ground sediment was dissolved in $\mathrm{HF}$ (40\%) and a $2.5 \mathrm{~mL}$ mixture of $\mathrm{HClO}_{4} / \mathrm{HNO}_{3}$. This digested sample was analyzed for selected elemental concentrations by ICP-OES (Perkin Elmer Optima 3000 Inductively Coupled PlasmaOptimal Emission Spectroscopy). The measured Ca concentration (total $\mathrm{Ca}$ ) was used to calculate the $\mathrm{CaCO}_{3}$ content (\% dry weight) of the solid phase.

The average sedimentation rate was estimated based on an assessment of the accumulated sediment inventory. As 

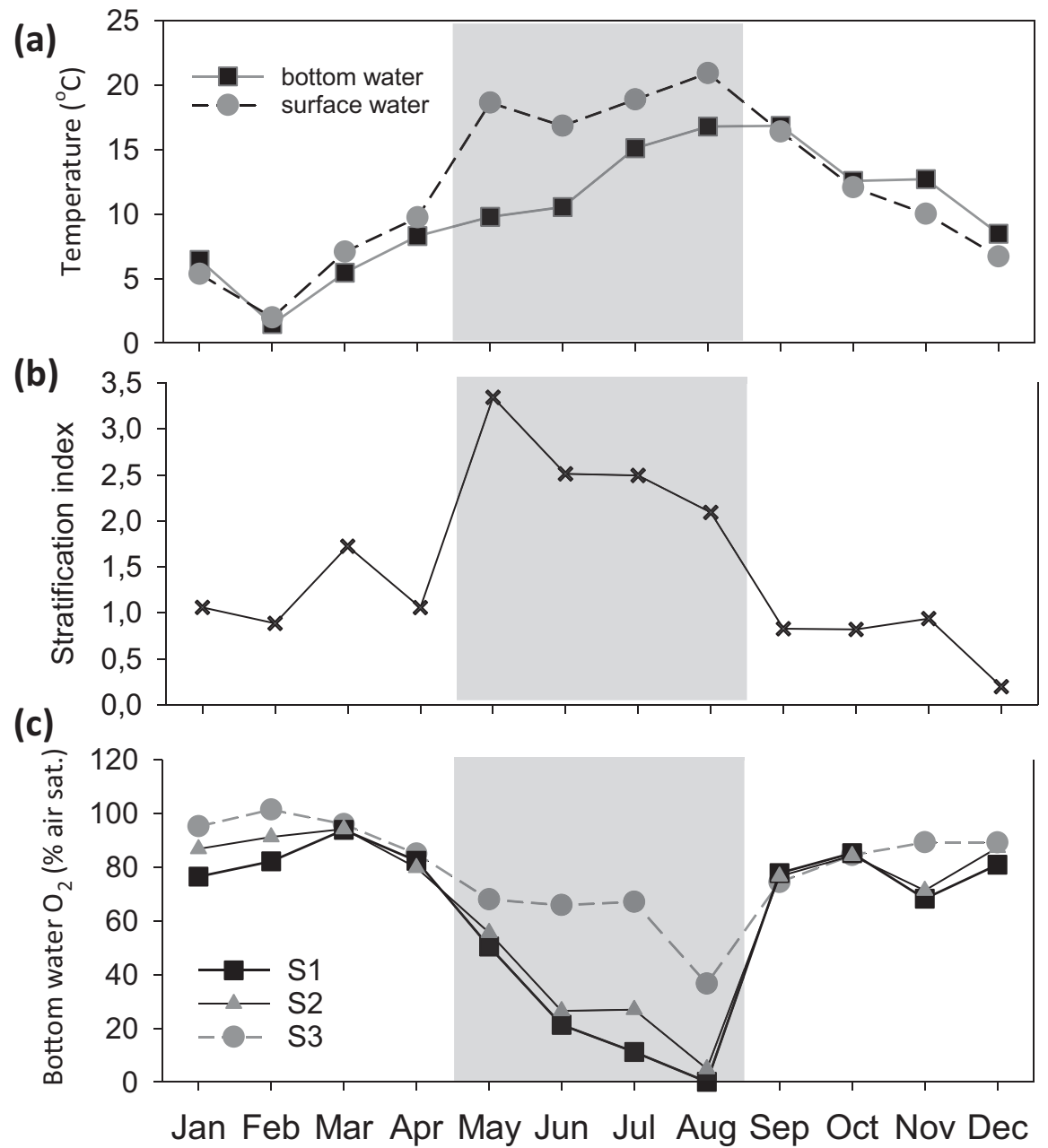

Fig. 2. (a) Surface and bottom water temperature at $\mathrm{S} 1$ (depth $34 \mathrm{~m}$ ), $\mathrm{S} 2$ (depth 23), and $\mathrm{S} 3$ (depth $17 \mathrm{~m}$ ); (b) stratification index, sigma, and (c) oxygen saturation in the bottom water at $\mathrm{S} 1-\mathrm{S} 3$, measured during each sampling campaign. Gray area indicates stratification period.

noted above, Lake Grevelingen was closed off from the North Sea by a dam in 1971, and since then, fine-grained, dark silt has accumulated within deeper lying areas. This sediment horizon is clearly distinguishable from the underlying gray estuarine sand, and hence, this transition can be used as a time marker (i.e., $41 \mathrm{yr}$ of sedimentation in 2012). A large number of sediment cores $(>20)$ were taken at each station and the depth $L$ of the transition horizon was measured with a ruler (precision $\sim 5 \%$ ). The sedimentation rate was subsequently calculated as $v=L / T$ where $T=41 \mathrm{yr}$.

\section{Macrofauna}

To determine the abundance (individuals $\mathrm{m}^{-2}$ ) and diversity (number of species) of macrofauna, at each site eight sediment cores were collected, during each monthly campaign (for a total surface area of $\sim 0.02 \mathrm{~m}^{2}$ for each site). The sediment from all cores was pooled and directly sieved (mesh size $1.0 \mathrm{~mm}$ ) on board. Subsequently, macrofauna were carefully handpicked and preserved in a $4 \%$ formalin solution stained with rose bengal. All individuals were identified to species level when possible using a stereomicroscope (Leica MZ16). Macrofauna functional diversity was estimated using the Shannon-Wiener diversity index $\left(H^{\prime}\right)$. SPIs were collected in August 2011 using an Ocean Imaging® SPI-lander system fitted with a Nikon DS 90 digital camera. The SPI system was deployed at four sites $(34 \mathrm{~m}, 23$ $\mathrm{m}, 16 \mathrm{~m}$, and $10 \mathrm{~m}$ ) along a line transect starting from S1, and six images were taken at each station. The average penetration depth of the SPI-wedge was $19 \mathrm{~cm}$ for the stations deeper than $20 \mathrm{~m}$ and $9 \mathrm{~cm}$ for the stations shallower than $20 \mathrm{~m}$. SPIs were analyzed using the SpiArcBase software (Romero-Ramirez et al. 2013).

\section{Statistical analysis}

In general, results are reported as the mean and standard deviation (s.d.) of $n$ replicate measurements. Porosity, $\mathrm{C}_{\text {org }}$ and $\mathrm{N}_{\text {org }}$ values are reported as mean $\pm \mathrm{s}$. d. in the uppermost $2 \mathrm{~cm}$ of sediment, as this sediment layer is prone to 
(a) Porosity

(b) $\quad \operatorname{Corg}(\%)$

(c) $\mathrm{CaCO}_{3}(\%)$
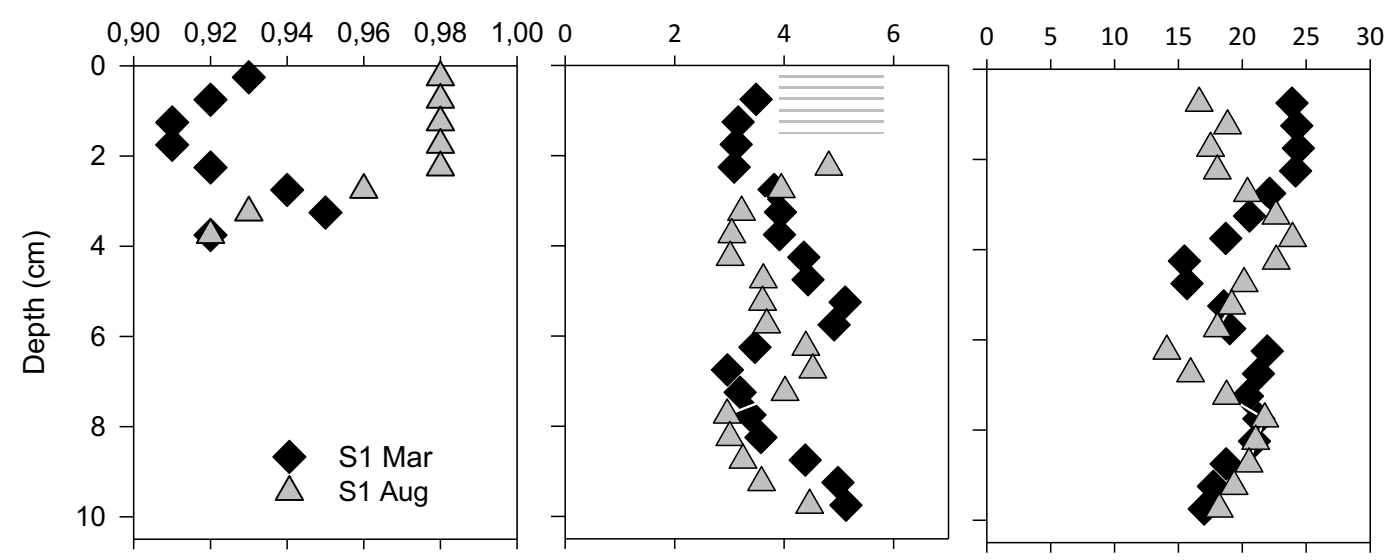

(d)

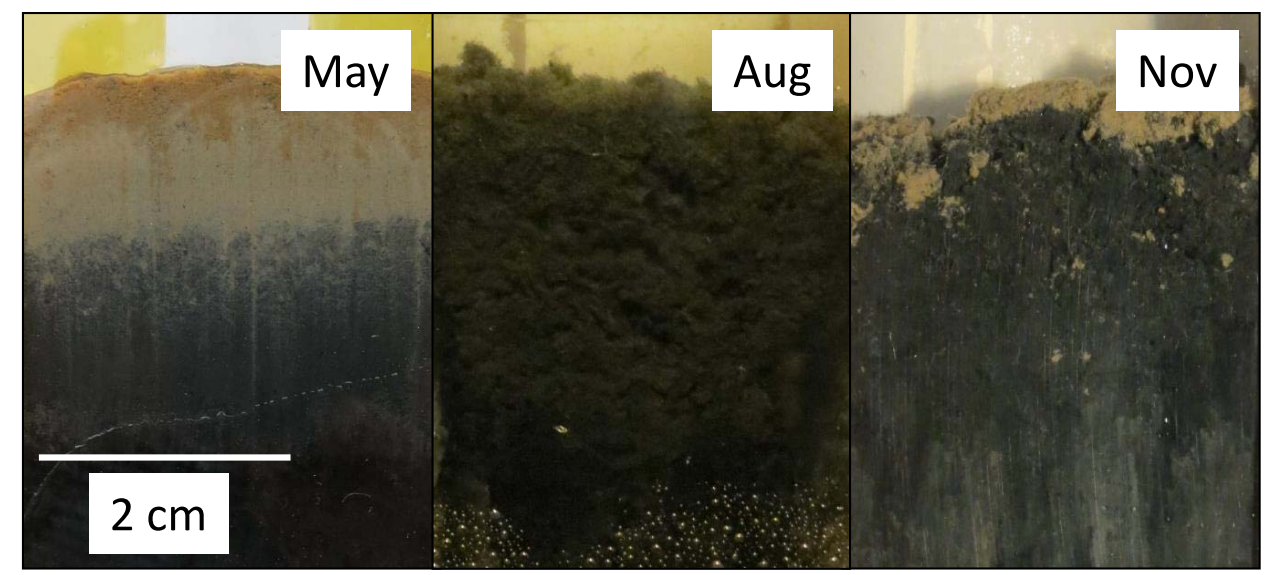

Fig. 3. (a) Depth profiles of porosity, (b) Corg (\%), and (c) CaCO3 for S1 in March (black diamonds) and August (gray triangles); (d) Cross cut of intact sediment cores from May, August, and November. Note that Corg values at $0-2 \mathrm{~cm}$ in Aug are not available (gray dashed area) as samples were lost during core handling.

seasonal variation, given the maximum sedimentation rate

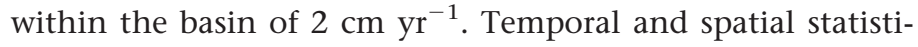
cal differences relative to these parameters were tested with a 2-way ANOVA, where values from March, May, August, and November were used as representative of the four seasons. Differences in TOU, DOU, DIC, TA, $\mathrm{NH}_{4}^{+}$, oxygen penetration depth (OPD), and macrofauna abundance across seasons and stations were analzsed using a 2-way ANOVA, after pooling months together in a "season" factor. Additionally, a post-hoc Tukey's test was used to compare seasonal differences for TOU, DOU, and OPD, and spatial differences for DIC and $\mathrm{NH}_{4}^{+}$. Within-station differences between TOU and DOU across time were identified with the paired Student's $t$ test. All statistical analyses were conducted in the open software R.

\section{Numerical models}

The shape of the oxygen depth profiles was described using two end-member models. In a first model, we assume a homogenous consumption of oxygen within the oxic zone. The resulting relation between the $\mathrm{OPD}(\delta)$ and the DOU is $\delta=2 \phi D_{\mathrm{s}} C_{0} / \mathrm{DOU}$, while the associated oxygen depth profile is given by $C(x)=C_{0}(1-x / \delta)^{2}$ (Bouldin 1968; Cai and Sayles 1996). In a second model, we assume that all the oxygen consumption takes place right at the OPD. The resulting relation between for the ODP and DOU becomes $\delta=\phi D_{s} C_{0} / D O U$, while the depth profile is given by $C(x)=C_{0}$ $(1-x / \delta)$ (Meysman et al. 2010). In these equations, $C_{0}$ denotes the bottom water oxygen concentration, $x$ is the sediment depth, $\phi$ is the mean porosity within the oxic zone, and Ds is the oxygen diffusion constant in the pore water.

\section{Results}

\section{Water column conditions}

The temperature of the bottom water (depth $=32 \mathrm{~m}$ ) varied throughout the year between $1.5^{\circ} \mathrm{C}$ in February and 
$16.9^{\circ} \mathrm{C}$ in September, whereas the temperature of the surface water (depth $=3 \mathrm{~m}$ ) showed a larger seasonal amplitude, varying between $2.0^{\circ} \mathrm{C}$ in February and $21.0^{\circ} \mathrm{C}$ in August (Fig. 2a). In January, the surface water was colder than the bottom water, but the salinity near the bottom was higher, thus stabilizing the water column. From February to April, the temperature of the surface and bottom water increased simultaneously, and as a result, their temperature difference remained within $1^{\circ} \mathrm{C}$. A strong warming of the surface water occurred in late spring, which established a larger temperature gradient between surface and deep water, thus leading to a stratified water column as indicated by the increased stratification index $\sigma$ (Fig. 2b). In July and August, the bottom water temperature increased, and so, the difference between surface and bottom water decreased again. The stratification index $\sigma$ remained high, although it was slightly lower than in previous months, decreasing from $3.3 \mathrm{~J} \mathrm{~m}^{-3}$ in May to $2.1 \mathrm{~J} \mathrm{~m}^{-3}$ in August (Fig. 2b). Stormy weather conditions and strong winds in September led to the disruption of the stratification, and the mixing of the water column (Hagens et al. 2015). In September and October, the stratification index $\sigma$ was low and there was no temperature difference between surface and bottom water, indicating a wellmixed water column, while in November and December, surface waters were again cooler than bottom waters.

The seasonal variation in the bottom water oxygen concentration was highly correlated with the seasonal stratification pattern, with greatest bottom water $\mathrm{O}_{2}$ in winter and fall, and lowest values in summer (Fig. 2c). The temporal evolution of the oxygen concentration at the intermediate depth station (S2) was similar to the deep station (S1) throughout the year, while the $\mathrm{O}_{2}$ evolution at the shallower station (S3) was distinct, with higher oxygen concentrations in summer. In early winter, the bottom water oxygen concentrations varied between $239 \mu \mathrm{mol} \mathrm{L}{ }^{-1}$ and $299 \mu \mathrm{mol} \mathrm{L}{ }^{-1}$ (76-94\% saturation) at S1, and from $255 \mu \mathrm{mol} \mathrm{L} \mathrm{L}^{-1}$ to $357 \mu \mathrm{mol} \mathrm{L} \mathrm{L}^{-1}$ (85$102 \%$ saturation) at S3. The stratification of the water column in May isolated the bottom waters, and limited the downward-mixing of oxygen-rich surface waters. Consequently, the oxygen concentrations dropped progressively, and at the end of June hypoxic levels were reached at S1 (28.8 $\mu$ mol $\mathrm{L}^{-1}$, corresponding to $11.1 \%$ saturation) and nearhypoxia was attained at S2 $\left(68.5 \mu \mathrm{mol} \mathrm{L}{ }^{-1}\right.$ or $\left.26.9 \%\right)$, whereas at S3 the oxygen saturation remained above $60 \%(165.9 \mu \mathrm{mol}$ $\left.\mathrm{L}^{-1}\right)$. More extensive oxygen depletion occurred in August, when the bottom water at S1 became anoxic $(<0.1$ $\left.\mu \mathrm{mol} \mathrm{L}{ }^{-1}\right), \mathrm{S} 2$ exhibited very low oxygen concentrations (12 $\mu$ mol $\left.\mathrm{L}^{-1}\right)$, whereas the oxygen levels at S3 remained just above the hypoxia threshold $\left(88 \mu \mathrm{mol} \mathrm{L} \mathrm{L}^{-1}\right.$ or $36 \%$ saturation). The disruption of the stratification in September led to water renewal in the deep layers of the basin, resulting in a re-oxygenation of these water masses, and as a result, similar bottom water $\mathrm{O}_{2}$ concentrations were observed in the three stations (74-78\% saturation). In November, the oxygen
Table 1. Sediment characteristics at the three sites. $\mathrm{N}_{\text {org, }} \mathrm{C}_{\text {org }}$ and $\mathrm{CaCO}_{3}$ numbers indicate mean value ( \pm s.d.) in the first $2 \mathrm{~cm}$ of sediment. The thickness of the brown layer was identified visually.

\begin{tabular}{|c|c|c|c|c|c|c|}
\hline & & \multirow[b]{2}{*}{$\mathrm{C} / \mathrm{N}$} & \multicolumn{2}{|c|}{$\%$} & \multicolumn{2}{|c|}{$\mathrm{mmol} \mathrm{m} \mathrm{m}^{-2} \mathrm{~d}^{-1}$} \\
\hline & & & Corg & $\mathrm{CaCO}_{3}$ & DOU & TOU \\
\hline \multirow[t]{3}{*}{ March } & S1 & 6.9 & $3.3 \pm 0.3$ & $23.8 \pm 0.8$ & $18.2 \pm 1.7$ & $30.1 \pm 0.6$ \\
\hline & S2 & 7.1 & $3.7 \pm 0.4$ & $20.7 \pm 0.1$ & $15.8 \pm 3.1$ & $26.5 \pm 0.2$ \\
\hline & S3 & 7.2 & $3.3 \pm 1.5$ & $20.7 \pm 2.5$ & $17.1 \pm 5.7$ & $26.1 \pm 1.7$ \\
\hline \multirow[t]{3}{*}{ May } & S1 & 6.9 & $5.4 \pm 0.4$ & $23.7 \pm 2.4$ & $20.9 \pm 3.4$ & $29.8 \pm 2.0$ \\
\hline & S2 & 7.1 & $3.8 \pm 0.3$ & $22.7 \pm 1.0$ & $17.6 \pm 3.2$ & $26.1 \pm 1.3$ \\
\hline & S3 & 7.2 & $3.7 \pm 0.1$ & $21.8 \pm 4.1$ & $23.5 \pm 2.0$ & $26.0 \pm 1.3$ \\
\hline \multirow[t]{3}{*}{ August } & S1 & 6.6 & $4.4 \pm 0.4$ & $18.3 \pm 1.3$ & - & - \\
\hline & S2 & 7.1 & $3.9 \pm 0.4$ & $21.0 \pm 0.3$ & - & $12.2 \pm 1.2$ \\
\hline & S3 & 7.3 & $4.2 \pm 0.2$ & $19.5 \pm 1.2$ & $13.9 \pm 2.1$ & $18.9 \pm 1.0$ \\
\hline \multirow[t]{3}{*}{ November } & S1 & 6.9 & $3.5 \pm 0.4$ & $21.8 \pm 0.8$ & $58.1 \pm 1.3$ & $68.3 \pm 6.0$ \\
\hline & S2 & 7.0 & $3.9 \pm 0.4$ & $21.3 \pm 0.4$ & $22.68 \pm 5.3$ & $22.3 \pm 0.1$ \\
\hline & S3 & 7.3 & $4.0 \pm 0.2$ & $19.3 \pm 1.2$ & $26.0 \pm 5.3$ & $19.4 \pm 0.7$ \\
\hline \multirow{3}{*}{$\begin{array}{l}\text { Yearly } \\
\text { average }\end{array}$} & S1 & - & - & - & $23.6 \pm 14.8$ & $32.1 \pm 19.9$ \\
\hline & S2 & - & - & - & $18.6 \pm 7.1$ & $23.4 \pm 4.7$ \\
\hline & S3 & - & - & - & $19.1 \pm 5.9$ & $23.3 \pm 3.6$ \\
\hline
\end{tabular}

concentrations slightly decreased at S1 and S2 to 68\% saturation, whereas they remained high at S3 (89\% saturation).

\section{Sediment characteristics}

The sediments at all sites in the Den Osse basin consist of fine mud (median grain size $16 \mu \mathrm{m}$; silt content 94\%), with a solid phase density of $2.60 \mathrm{~g} \mathrm{~cm}^{-3} \pm 0.03 \mathrm{~g} \mathrm{~cm}^{-3}(n=4)$, which is a typical value for siliciclastic sediments. The porosity in the uppermost $2 \mathrm{~cm}$ was different among stations (2-way ANOVA, $F_{2,48}=10.4, p<0.01$ ), and also showed a seasonal variation (2-way ANOVA, $F_{3,48}=17.4, p<0.001$ ), with minimum values $(0.92)$ reached in spring and maximum values (0.98) in summer (Fig. 3a). The porosity slightly decreased from the surface to 4 -cm depth (Fig. 3a). This high porosity in the first few centimeters (0.92-0.98) was associated with a fluffy surface layer at all sites in summer, which was easily re-suspended on disturbance.

Sediment cores showed a notable transition between the older gray estuarine sand and the overlying dark accumulated silt horizon. This transition depth $(L)$ strongly differed between stations (S1: $81 \mathrm{~cm} \pm 5 \mathrm{~cm}$; S2: $33 \mathrm{~cm} \pm 7 \mathrm{~cm}$; S3: 15 $\mathrm{cm} \pm 3 \mathrm{~cm}$ ), and the resulting estimate of a mean sedimentation rate over the $41 \mathrm{yr}$ enclosure period increased with water depth (S1: $2.0 \mathrm{~cm} \mathrm{yr}^{-1} \pm 0.1 \mathrm{~cm} \mathrm{yr}^{-1} ; \mathrm{S} 2: 0.80$ $\mathrm{cm} \mathrm{yr}{ }^{-1} \pm 0.17 \mathrm{~cm} \mathrm{yr}^{-1}$; S3: $\left.0.36 \mathrm{~cm} \mathrm{yr}^{-1} \pm 0.07 \mathrm{~cm} \mathrm{yr}^{-1}\right)$. The estimated sedimentation rate at S1 was consistent with a previous assessment via ${ }^{137} \mathrm{Cs}$ and ${ }^{210} \mathrm{~Pb}$ radionuclide dating, which provided a similar estimate of $2.2 \mathrm{~cm} \mathrm{yr}^{-1}$ (Donders et al. 2012). 
Overall, the sediment showed a high organic carbon content, which revealed clear variations with depth over the first 10 centimeter (Fig. 3b). The sediment organic carbon content in the upper $2 \mathrm{~cm}$ significantly differed with seasons (2-way ANOVA, $F_{3,51}=4.6, p<0.01$ ), but not across stations (2-way ANOVA, $\left.F_{2,51}=1.1, p=0.33\right)$, and ranged between $3.3 \%$ and $5.4 \%$ (mean value across stations, depth, and time: $4.0 \% \pm$ $0.6 \%$; Table 1). Throughout the seasons, the mean molar $\mathrm{C}: \mathrm{N}$ ratio in the upper $2 \mathrm{~cm}$ of sediment decreased with water depth, from $6.9 \pm 0.1$ at $\mathrm{S} 1$, over $7.1 \pm 0.1$ at $\mathrm{S} 2$, and $7.2 \pm 0.1$ at S3. All stations showed a similarly high $\mathrm{CaCO}_{3}$ content with a mean of $21.6 \% \pm 1.6 \%$ across stations, depth, and time (Table 1; Fig. 3c). The oscillations with depth of organic carbon and $\mathrm{CaCO}_{3}$ are inversely correlated, and suggest a seasonal shift in the composition of the deposited sediment.

The visual appearance and coloration of the surface sediment layer changed substantially throughout the year, suggesting marked changes in redox conditions and geochemical cycling (Fig. 3b). From January to May, we observed a brown oxidized surface layer of approximately $2 \mathrm{~cm}$ (Fig. 3d) at all stations, which gradually decreased in thickness in May, as the sediments were evolving to a more reduced state. In summer, a highly porous "fluffy" layer was present on top (Fig. 3d), the thickness of which increased with water depth $(40 \mathrm{~mm}$ at S1, $23 \mathrm{~mm}$ at S2, and $11 \mathrm{~mm}$ at S3 in August). In fall, patches of light-brown oxidized sediment appeared, which were distributed heterogeneously within the surface fluffy layer. Marine snow was abundant in the deep bottom waters of Lake Grevelingen (video observations via GoPro camera attached to sediment corer; data not shown), and so these light-brown sediment patches might have resettled after being resuspended and oxidized in contact with oxic water, or might have been transported laterally (Fig. 3d).

\section{Benthic fauna}

SPIs were taken along a depth transect (Fig. 4a) during a period of severe bottom water oxygen depletion (August 2011). SPIs clearly revealed an increasing impact of hypoxia on geochemistry and infauna with water depth. The sediments at the two deepest stations (34- and 23-m depth) were entirely black, did not show any sign of an apparent redox potential discontinuity (aRPD), and had no signs of biogenic structures. These sediments also had a sizeable fluffy layer, the thickness of which increased with water depth (from $9.7 \mathrm{~mm}$ at $10-\mathrm{m}$ (a)
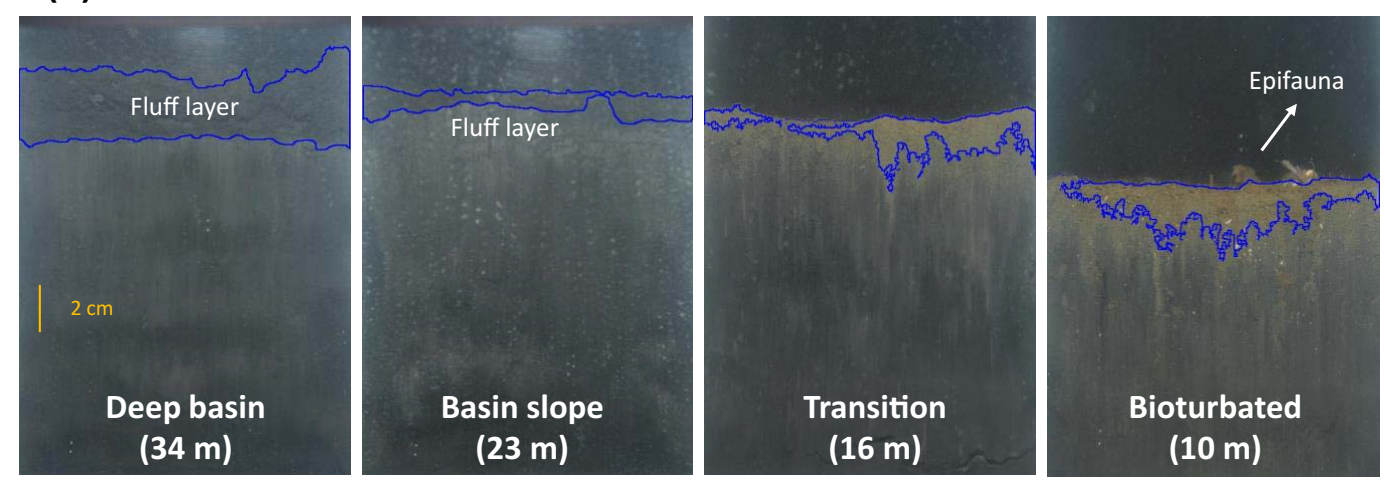

(b)

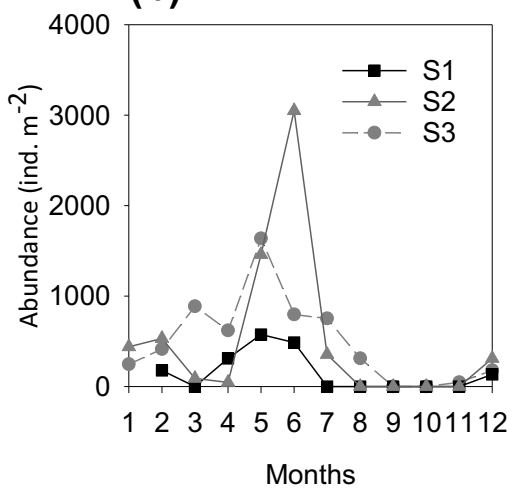

(c)

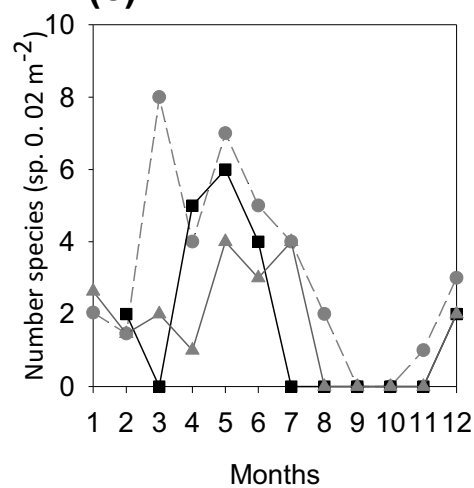

(d)

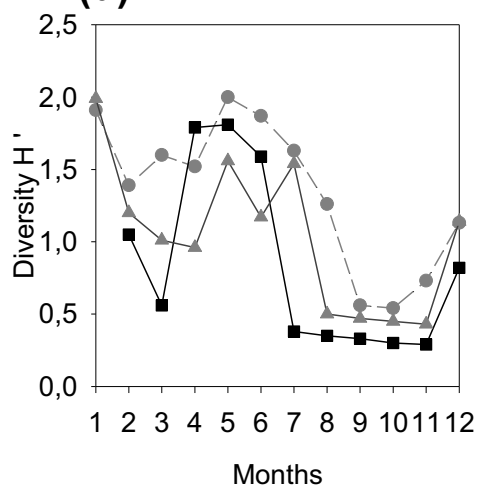

Fig. 4. (a) SPI-images at four stations distributed along a depth transect in Den Osse basin in August 2011. Area delimited by the blue line indicates the distribution of the fluffy layer (at $34 \mathrm{~m}$ and $23 \mathrm{~m}$ ), the oxidized layer (at $6 \mathrm{~m}$ ), and the zone colonized by epifauna (at $10 \mathrm{~m}$ ). (b) Macrofauna abundance, (c) number of species, and (d) Shannon-Wiener diversity index $\left(H^{\prime}\right)$ over the year at the three stations. 

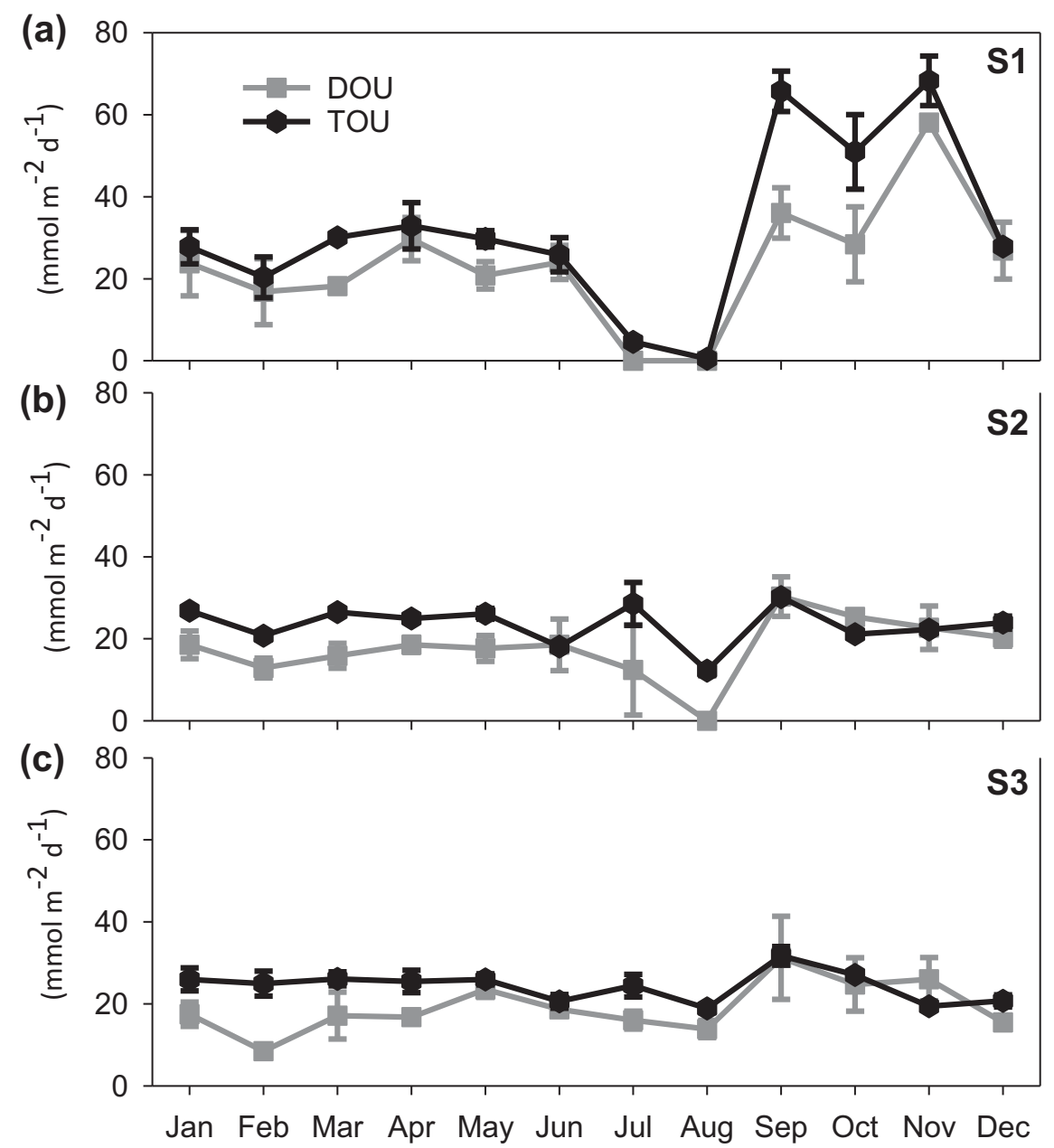

Fig. 5. Sedimentary oxygen consumption measured as TOU (black) and DOU (gray) throughout 2012 at (a) S1, (b) S2, and (c) S3. Error bars indicate the standard deviation calculated over three TOU and DOU replicates.

depth to $32 \mathrm{~mm}$ at 34-m depth). SPIs from the station located at $16 \mathrm{~m}$ water depth showed a thin aRPD of around $8 \mathrm{~mm}$, but did not exhibit visible burrow structures or other indications of macrofauna. SPIs from the shallowest station $(10 \mathrm{~m}$ water depth) revealed a larger oxidized layer and sediments that were colonized by epifauna, suggesting bioturbation activity.

The benthic fauna at the study site in 2012 was generally sparse, with a dominance of small polychaetes such as Streblospio benedicti, Scoloplos armiger, Chone duneri, and Capitella capitata and juvenile bivalves such as Corbula gibba and Abra nitida. Overall, the macrofauna abundance and number of species exhibited strong seasonal variation (2-way ANOVA, $F_{3,29}=2.4, p=0.09$ and $F_{3,29}=8.9, p<0.001$, respectively), but values were not significantly different among stations (2way ANOVA, $F_{2,29}=2.5, p=0.10$ and $F_{2,29}=2.8, p=0.07$, respectively). The population density showed a clear seasonal pattern, which was similar across the three stations (Fig. 4b). In September, right after the summer hypoxia, no macrofauna were found in the sediments, and the sediments remained devoid of fauna until November. When repopulation began in December, the small deposit-feeding polychaetes Scoloplos armiger and Capitella capitata were the first species to re-appear. Population densities remained very low in winter and early spring, and only in late spring did the macrofauna abundance start to increase (Fig. 4b). At S1 and S3, greatest densities were observed in May (of 575 ind. $\mathrm{m}^{-2}$ and 1636 ind. $\mathrm{m}^{-2}$, respectively), whereas at S2 the community reached its peak in June at a density of 3050 ind. $\mathrm{m}^{-2}$. In summer, the macrofauna entirely disappeared, first in July the deepest Sta. S1, then followed by S2 in August. At Sta. S3, where the bottom water remained above the hypoxia threshold, the population also declined, but more slowly and here macrofauna were gone by September.

The macrofaunal diversity was generally low with 26 species detected in total, and at most eight species were present conjointly in one station at the same time point. The seasonal pattern in number of species (Fig. 4c) was similar to that of population density, although the number of species present showed high fluctuations in spring. The Shannon- 
Wiener diversity index ( $H^{\prime}$ showed a clear seasonal pattern, with highest values from May to June (Fig. 4d). The highest $H^{\prime}=2.0$ was obtained in May at S3.

\section{Seasonality in sedimentary oxygen uptake}

Throughout 2012, the deepest station (S1) showed the strongest seasonality in the TOU. The TOU remained fairly constant from January to June, ranging between 20.4 mmol $\mathrm{O}_{2} \mathrm{~m}^{-2} \mathrm{~d}^{-1}$ and $29.8 \mathrm{mmol} \mathrm{O}_{2} \mathrm{~m}^{-2} \mathrm{~d}^{-1}$, with slightly lower values in February (Fig. 5). The advent of low bottom water oxygen conditions in July was accompanied by a substantial drop in TOU at S1, which-as expected-approached zero in August when the bottom water became completely devoid of oxygen. The re-introduction of oxygen to the bottom layers, generated a surge in the TOU at S1 in September, which lasted until November, when the highest TOU value (68.3 mmol $\mathrm{m}^{-2} \mathrm{~d}^{-1}$ ) was recorded over the year 2012. The TOU values decreased again in December, and approached the level observed in January 2012, thus completing the yearly cycle.

The TOU at the other two sites, S2 and S3, showed less pronounced seasonal fluctuations compared to the deepest site. As observed for S1, the TOU remained fairly constant from January to May (mean value over this period at S2: $25.0 \mathrm{mmol} \mathrm{m} \mathrm{m}^{-2} \mathrm{~d}^{-1} \pm 2.2 \mathrm{mmol} \mathrm{m} \mathrm{m}^{-2} \mathrm{~d}^{-1}$; and at S3: 25.7 mmol m${ }^{-2} \mathrm{~d}^{-1} \pm 0.4 \mathrm{mmol} \mathrm{m}^{-2} \mathrm{~d}^{-1}$ ). At both $\mathrm{S} 2$ and $\mathrm{S} 3$, the TOU dropped slightly in June, increased in July, and then decreased again in August, although with a larger drop at S2 compared to S3. Similar to Sta. S1, the sediment responded to the reintroduction of oxygen in September by an increase in TOU, after which the values decreased again in the following months. The yearly mean TOU values were $32.1 \mathrm{mmol} \mathrm{O}_{2} \mathrm{~m}^{-2} \mathrm{~d}^{-1} \pm 3.6$ mmol $\mathrm{O}_{2} \mathrm{~m}^{-2} \mathrm{~d}^{-1}$ at $\mathrm{S} 1,23.4 \mathrm{mmol} \mathrm{O}_{2} \mathrm{~m}^{-2} \mathrm{~d}^{-1} \pm 1.0$ mmol $\mathrm{O}_{2} \mathrm{~m}^{-2} \mathrm{~d}^{-1}$ at $\mathrm{S} 2$, and $24.3 \mathrm{mmol} \mathrm{O}_{2} \mathrm{~m}^{-2} \mathrm{~d}^{-1} \pm 1.8$ mmol $\mathrm{O}_{2} \mathrm{~m}^{-2} \mathrm{~d}^{-1}$ at S3. Two-way ANOVA indicated that the TOU rates were not different between stations $\left(F_{2,24}=1.9\right.$, $p=0.16$ ), but significantly differed over the four seasons $\left(F_{3,24}=11.2, p<0.001\right)$. A post hoc test revealed that TOU was higher in fall (Tukey's HSD test, $p<0.001$ ).

The DOU scaled with the TOU at all three sites, suggesting that most of the oxygen uptake was sustained by diffusive transport across the sediment-water interface. At Sta. S1, the DOU showed the same strong seasonality as the TOU (Fig. 5). No systematic difference between TOU and DOU was apparent in spring and summer, but TOU exceeded DOU from September until November. This difference between TOU and DOU in fall can be either due to the high consumption (strong gradients in pore water $\mathrm{O}_{2}$ make the DOU estimate less precise) or due heterogeneous microtopography created by surficial mats of sulfur-oxidizing bacteria (as further discussed below). At sites S2 and S3, the TOU/ DOU ratio showed the reverse response compared to S1: the TOU exceeded DOU in late spring, when the highest macrofauna abundance was recorded (thus suggesting a small faunal respiration [FR] and bio-irrigation effect), but no systematic difference was apparent in fall, when macrofauna was absent. Theoretically, the TOU should always be larger than the DOU, as the TOU incorporates all sources of oxygen demand (i.e., due to physical advection, diffusion, bioirrigation, and FR). This condition was fulfilled for all stations and months, except for three instances (April S1, October S2, and November S3). However, a student $T$-test showed that also in these latter three cases, the values of TOU and DOU were not statistically different $(t=-0.6$, df $=2.4$, $p=0.62$ ).

The yearly mean DOU values were $23.6 \mathrm{mmol} \mathrm{O}_{2}$ $\mathrm{m}^{-2} \mathrm{~d}^{-1} \pm 14.8 \mathrm{mmol} \mathrm{O}_{2} \mathrm{~m}^{-2} \mathrm{~d}^{-1}$ at $\mathrm{S} 1$, and 18.6 mmol $\mathrm{O}_{2} \quad \mathrm{~m}^{-2} \mathrm{~d}^{-1} \pm 7.1 \quad \mathrm{mmol} \mathrm{O}_{2} \quad \mathrm{~m}^{-2} \mathrm{~d}^{-1}$ and 19.1 mmol $\mathrm{O}_{2} \mathrm{~m}^{-2} \mathrm{~d}^{-1} \pm 5.9 \mathrm{mmol} \mathrm{O}_{2} \mathrm{~m}^{-2} \mathrm{~d}^{-1}$, at S2 and S3, respectively (Table 1 ). The DOU rates differed between stations (2-way ANOVA, $F_{2,95}=3.5, p<0.05$ ), and were also different among seasons (2-way ANOVA, $F_{3,95}=26.0$, $p<0.001$ ), with fall showing higher rates (Tukey's HSD test, $p<0.001)$.

\section{DIC, TA, and $\mathrm{NH}_{4}^{+}$fluxes}

The seasonal pattern of the fluxes of DIC, TA, and $\mathrm{NH}_{4}^{+}$ across the sediment-water interface is shown in Fig. 6. The DIC flux at S1 was generally high and showed strong variations throughout the year (Fig. 6a). Fluxes increased from March to June, and showed a small decrease during hypoxia (Fig. 6a). The DIC efflux peaked again in September (139 mmol $\mathrm{m}^{-2} \mathrm{~d}^{-1}$ ), when the bottom water got re-oxygenated, and decreased from October onwards, in concert with the decline in bottom water temperature (Fig. 2a). At S2 and S3, the seasonal pattern of the DIC efflux tracked the bottom water temperature (Fig. 2a), with values being higher in spring-summer and lower in winter. The release of DIC significantly differed with water depth (2-way ANOVA, $\left.F_{2,54}=25.6, p<0.001\right)$, with higher fluxes at the deepest Sta. S1 (Tukey's HSD test, $p<0.001$ ).

The seasonal pattern of the $\mathrm{NH}_{4}^{+}$flux resembled well that of the DIC flux at the three stations (Fig. 6b). Seasonal variation in the $\mathrm{NH}_{4}^{+}$flux was significant (2-way ANOVA, $\left.F_{3,72}=18.2, p<0.001\right)$, and there was a significant difference among stations (2-way ANOVA, $F_{2,72}=28.4, p<0.001$ ), with S1 showing the highest $\mathrm{NH}_{4}^{+}$release from the sediment (Tukey's HSD test, $p<0.001$ ).

Alkalinity (TA) was released from the sediment over the entire year 2012, with only one exception, in November at S1, where was observed an uptake rather than a release of TA (Fig. 6c). Although TA fluxes did not exhibit a strong spatial variation (2-way ANOVA, $F_{2,24}=3.1, p=0.06$ ), the seasonal variations were pronounced (2-way ANOVA, $F_{3,24}=8.6$, $p<0.001)$.

\section{Mineralization rate and respiratory coefficient}

The effluxes of DIC and $\mathrm{NH}_{4}^{+}$from the sediment provide two independent proxies for the mineralization rate (i.e., the 

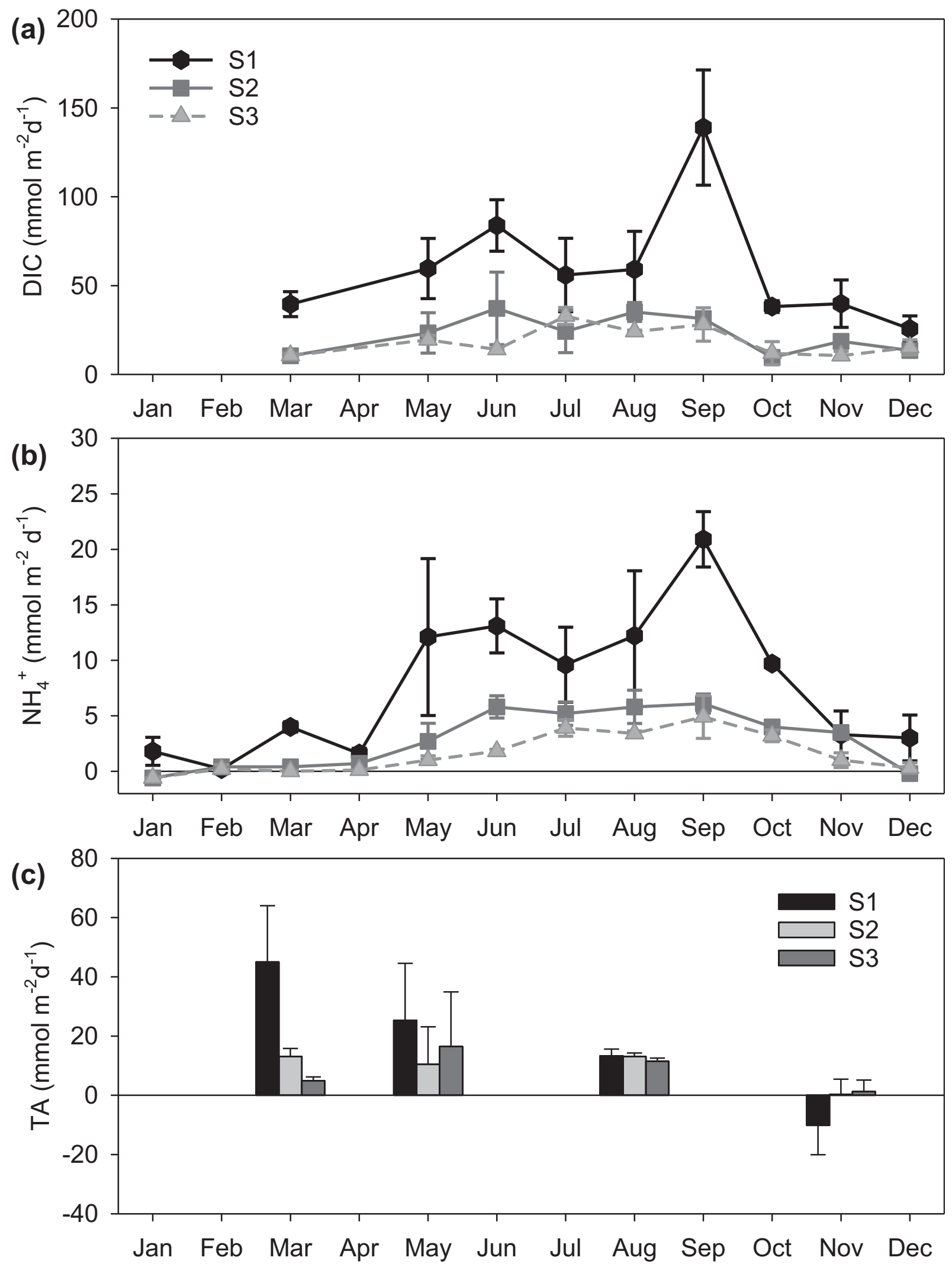

Fig. 6. Benthic fluxes of (a) DIC, (b) $\mathrm{NH}_{4}^{+}$, and (c) TA at the three stations throughout 2012. Error bars indicate standard deviation among 2-3 replicates. Measurements were performed in March and from May onwards for DIC, monthly for $\mathrm{NH}_{4}^{+}$, and in March, May, August, and November for TA. 


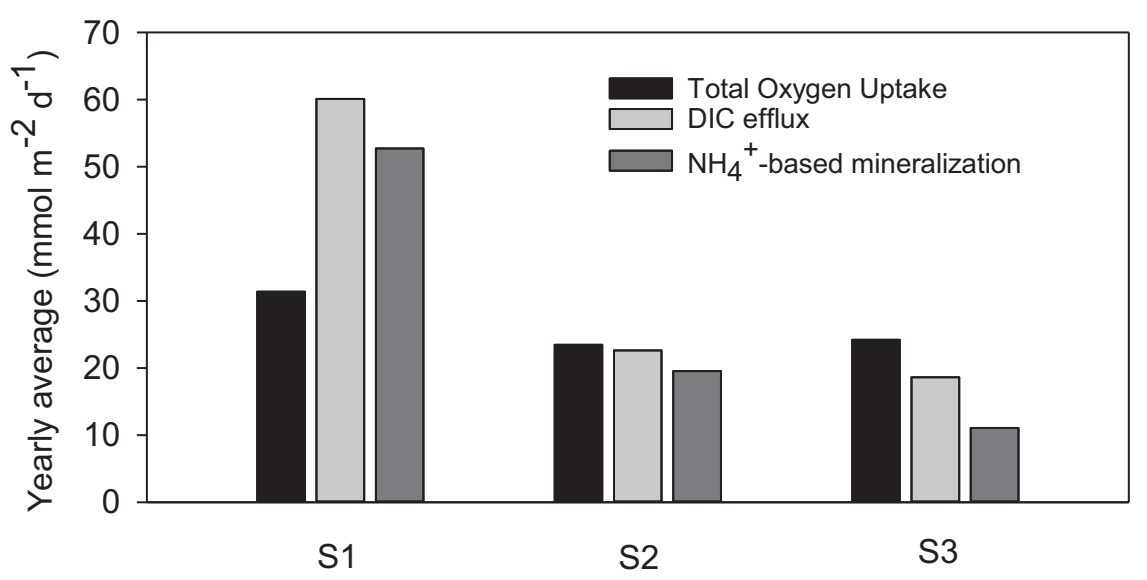

Fig. 7. Yearly average of TOU, DIC efflux, and $\mathrm{NH}_{4}^{+}$-based mineralization at $\mathrm{S} 1-\mathrm{S} 3$. The $\mathrm{NH}_{4}^{+}$-based mineralization was estimated based on measured $\mathrm{NH}_{4}^{+}$flux $\times \mathrm{C} / \mathrm{N}$ ratio of 6.9 .

rate of organic matter decomposition), assuming that (1) the sediment resides in a steady state and (2) that no other consumption or production processes of DIC (e.g., carbonate precipitation/dissolution) or $\mathrm{NH}_{4}^{+}$(e.g., nitrification) are taking place (Canfield 1993; Glud 2008). The efflux of $\mathrm{NH}_{4}^{+}$can be converted into an equivalent mineralization rate by multiplication with the $\mathrm{C}: \mathrm{N}$ ratio of sedimentary organic matter (Table 1). The $\mathrm{NH}_{4}^{+}$-based mineralization rate closely matches the measured DIC flux (Fig. 6), suggesting that carbonate precipitation or dissolution are likely not important. This is confirmed by the alkalinity effluxes ( -10 to 45 mmol $\mathrm{m}^{-2} \mathrm{~d}^{-1}$; Fig $6 \mathrm{c}$ ), which are generally much smaller than DIC effluxes ( 26 to $139 \mathrm{mmol} \mathrm{C} \mathrm{m}^{-2} \mathrm{~d}^{-1}$ ). Assuming the TA flux is entirely generated by carbonate dissolution, and then 0.5 times the TA flux would represent the DIC release by carbonate dissolution. The latter only provides a relatively small contribution to the total DIC flux $(21 \%$ in May, 11\% in August), and hence, we conclude that organic matter mineralization provides the major source of DIC production in the sediment.

The respiratory quotient $\mathrm{RQ}$ is defined as the ratio of sedimentary DIC efflux over sedimentary $\mathrm{O}_{2}$ consumption. Figure 7 plots the average DIC-efflux, the $\mathrm{NH}_{4}^{+}$-based mineralization rate and TOU over 2012 for the three stations. There is a remarkable depth dependency of the yearly average $\mathrm{RQ}$, which is high at $\mathrm{S} 1(\mathrm{RQ}=1.6 \pm 0.9)$, nearly one at $\mathrm{S} 2(\mathrm{RQ}=1.1 \pm 0.8)$, and low at $\mathrm{S} 3(\mathrm{RQ}=0.8 \pm 0.3)$. Accordingly, the deepest site $\mathrm{S} 1$, shows an apparent deficit in oxygen consumption compared to mineralization, which may be explained by the high mineralization and the high sediment accumulation at this site. An oxygen deficit can be created when iron mono-sulfide $(\mathrm{FeS})$ and pyrite $\left(\mathrm{FeS}_{2}\right)$ escape reoxidation by oxygen through burial in deeper sediment horizons. Sulfide burial is stimulated by high sediment accumulation combined with high mineralization, which favors anoxic mineralization pathways (thus inducing high sulfide production through sulfate reduction). Recently, Seitaj et al. (2015) calculated an average burial rate of solid sulfur compounds of $3 \mathrm{mmol} \mathrm{S} \mathrm{m} \mathrm{m}^{-2} \mathrm{~d}^{-1}$ at $\mathrm{S} 1$, which hence provides an oxygen deficit of $6 \mathrm{mmol} \mathrm{S} \mathrm{m} \mathrm{m}^{-2} \mathrm{~d}^{-1}$. In contrast, the shallowest site S3 shows an apparent surplus of oxygen consumption compared to both DIC-efflux and $\mathrm{NH}_{4}^{+}$-based mineralization. As Sta. S3 experiences oxygenated bottom waters throughout the year, one explanation for this could be nitrification, which results in a lowered $\mathrm{NH}_{4}^{+}$efflux from the sediment, and hence leads to an underestimation of the $\mathrm{NH}_{4}^{+}$based mineralization rate (Cook et al. 2010). Overall, the strong depth dependency of the respiratory quotient in the sediments of Lake Grevelingen remains incompletely understood and requires further study.

\section{Oxygen penetration depth}

Sediments at the Lake Grevelingen site exhibited a shallow OPD, ranging between $0.8 \mathrm{~mm}$ and $4.5 \mathrm{~mm}$ across seasons and sites (Fig. 8 a,b). Station S1 showed the lowest mean OPD $(1.1 \mathrm{~mm} \pm 0.6 \mathrm{~mm})$, and the OPD increased at shallower water depths (S2: $1.6 \mathrm{~mm} \pm 0.8 \mathrm{~mm}$ and S3: 1.9 $\mathrm{mm} \pm 1.0 \mathrm{~mm})$. The OPD significantly varied between stations (2-way ANOVA, $F_{2,96}=17.6, p<0.001$ ) and seasons (2way ANOVA, $\left.F_{3,96}=38.0, p<0.001\right)$, with higher OPDs present in winter (Tukey's HSD test, $p<0.001$ ).

\section{Discussion}

\section{Impact of seasonal hypoxia on benthic fauna}

Over the last three decades, Lake Grevelingen has experienced a regular pattern of bottom water oxygen depletion occurring in summer (Seitaj et al., 2015). Such seasonal hypoxia strongly impacts the benthic fauna community composition in coastal systems (Diaz and Rosenberg 1995; Levin et al. 2009). As oxygen levels drop animals may suffer from a variety of stresses, ultimately leading to their disappearance as oxygen levels approach anoxia (Diaz and Rosenberg 1995; 

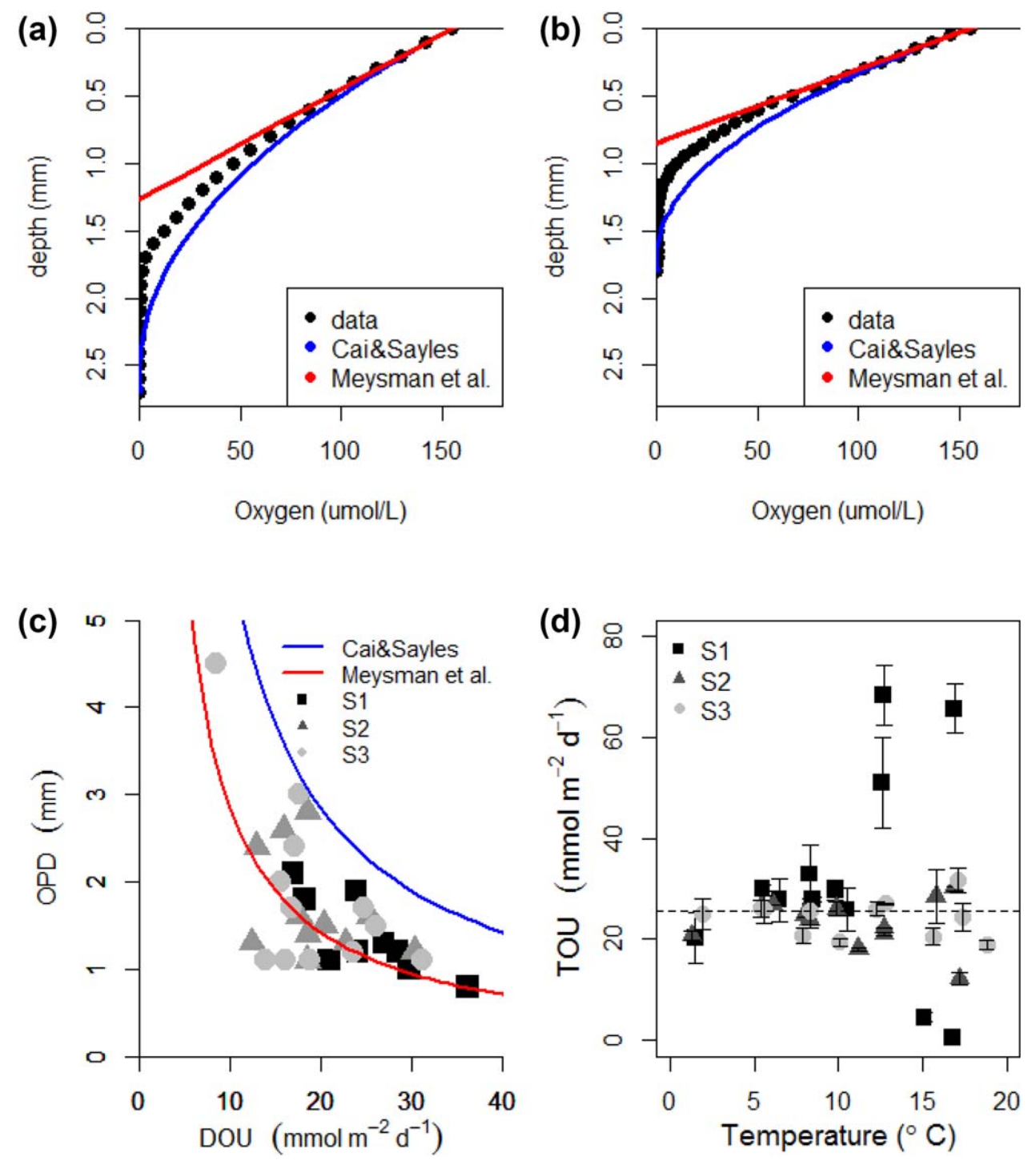

Fig. 8. Measured oxygen depth profiles in (a) February and (b) November. Red lines indicate the simulated oxygen depth profile, where $C(x)=C_{0}$ $(1-x / \delta) 2$ (Cai and Sayles 1996). Blue lines indicate the simulated oxygen depth profile, where $C(x)=C_{0}(1-x / \delta)$. (c) OPD-DOU relation. The solid blue line indicates the relation as predicted from $\delta=2 \times \phi \times D_{\mathrm{s}} \times C_{0}$ (Cai and Sayles 1996). The solid red line indicates $\delta=\phi \times D_{\mathrm{s}} \times C_{0}$ (Meysman et al. 2010) the black circles indicate measured data. Abbrevations: $C_{0}$ denotes the yearly average bottom water oxygen concentration over the three stations $\left(223.8 \mu \mathrm{mol} \mathrm{L}{ }^{-1}\right), \delta$ indicates the calculated OPD, and $x$ is the sediment depth, $\phi$ is the yearly average porosity, and $D_{s}$ oxygen diffusion constant in sediments. (d) TOU vs. bottom water temperature. Dashed line indicates yearly average temperature over the three stations $\left(T=13.8^{\circ} \mathrm{C}\right)$. Error bars indicate the standard deviation calculated over three TOU replicates.

Vaquer-Sunyer and Duarte 2008; Steckbauer et al. 2011). The conventional threshold level for hypoxia is $2 \mathrm{mg} \mathrm{L}^{-1}$ or 63 $\mu \mathrm{mol} \mathrm{L} \mathrm{L}^{-1}$, although thresholds vary widely between different organism groups, with crustaceans and fish being among the most sensitive taxa (Vaquer-Sunyer and Duarte 2008).

As also observed here (Fig. 4), the benthic macrofaunal communities undergo seasonal changes that depend on the oxygen availability in the bottom water (Jørgensen 1980; Holland et al. 1987; Ritter and Montagna 1999), and the response of benthic faunal community to oxygen depletion appears to follow a systematic successional pattern. During the hypoxic or anoxic period, the macrofauna abundance and biomass, as well as the species richness, rapidly declines, due to emigration of larger mobile species (e.g., crustaceans) or the mortality of sedentary species as a result of oxygen depletion (Diaz and Rosenberg, 1995; Levin et al., 2009 and references therein). After the anoxic period, when bottom waters are replenished with oxygen, the benthic environment is recolonized by mainly juvenile macrofauna. This recolonization process classically follows a successional pattern, with small-sized opportunistic species establishing first, and larger, deeper burrowing fauna only arriving in a later 
stage (Pearson and Rosenberg, 1978; Rosenberg et al., 2002; Van Colen et al., 2008; Steckbauer et al., 2011). Finally, when the following hypoxic event occurs, the succession pattern is started again.

The actual recovery pattern of the benthic faunal community depends on the frequency of the hypoxic events. In a seasonally hypoxic system, such as Lake Grevelingen, the oxygen depletion develops each year in the bottom waters, which impedes the establishment of a well-developed macrofauna community. Due to the frequency of stressors, the community is kept in an early successional state, and is typically depauperate and composed of small-sized, short-lived, and opportunistic species (Diaz and Rosenberg 1995; Rosenberg et al. 2002). These small fauna only create shallow dwelling zones, and hence, they are capable of limited bioturbation (Diaz and Rosenberg 1995; Levin et al. 2009). This pattern was clearly documented in our SPI imaging, which revealed a sharp transition in communities (Fig. 4a) above and below the water depth affected by seasonal hypoxia $(\sim 15 \mathrm{~m})$. The shallower areas of the lake $(<15 \mathrm{~m})$ host a rich faunal community (Wetsteyn 2011), while the deeper areas host a poor community that is only present during a limited period. Our results show that the deeper sediments remain devoid of macrofauna until November, and that small polychaetes and juvenile bivalves start colonizing the sediment in spring. However, overall abundances and species number remain low. Low oxygen conditions in summer disrupt the recolonization, and impede the establishment of large burrowing or deep-irrigating animals, which require multi-annual recruitment cycles.

Although the bioturbation intensity was not quantified directly, our macrofauna and SPI data provide a qualitative estimation of the seasonal sediment reworking. At all stations located below $15 \mathrm{~m}$ water depth, the dominant individuals were small, surface deposit-feeding polychaetes, which only burrow in the first $1-2 \mathrm{~cm}$ of the sediment and have low particle processing rates per individual (Diaz and Rosenberg 1995). Bivalve individuals were also typically small, suggesting a recent settlement of juveniles with a limited capacity to rework the sediment. Accordingly, only in late spring and early summer, there may be some moderate biological working of the sediment. Still, during video observations in winter and spring (GoPro camera attached to the gravity corer; data not included), we were able to observe large crabs (Cancer pagurus) moving along the sediment surface at all sites as well small shrimp burrowing. In addition, ample trail marks of large crustaceans were visible in the video footage, as faunal imprints exposed the underlying black sediment. These large epifauna were not captured by our coring procedure, and most likely migrated to deeper water depths at times of sufficient bottom water oxygenation. These epifauna could, therefore, increase the rate of surficial sediment mixing in winter and spring.

\section{Impact of fauna and large bacteria on sedimentary oxygen uptake}

Burrow construction and other sediment reworking by fauna (re)expose anoxic sediments to oxygen, and extend the oxic-anoxic interface area (Fenchel 1996; Kristensen 2000), and this increases the reoxidation rates of reduced compounds in sediments (Banta et al. 1999; Kristensen 2001). In studies on sedimentary $\mathrm{O}_{2}$ uptake, the decomposition $\mathrm{TOU}=\mathrm{DOU}+\mathrm{FR}+$ irrigational oxygen uptake (IOU) may be used, which includes the DOU across the sediment-water interface, the FR, and the IOU, representing the $\mathrm{O}_{2}$ consumption in the oxygenated zone around burrows (Archer and Devol 1992; Wenzhöfer and Glud 2004; Meysman et al. 2010). The contribution of fauna is termed the faunamediated oxygen uptake (FMOU $=$ FR + IOU), which can be a dominant component in coastal sediments, accounting for $50-90 \%$ of the TOU (Wenzhöfer and Glud 2004).

Nevertheless, at the three sites investigated, the FMOU contribution was not substantial. As noted above, the macrofauna community exhibited low abundances compared to other coastal habitats and mainly consisted of small polychaetes that created small and shallow burrows (e.g., Scoloplos armiger and Capitella capitata). Accordingly, the respiration of the fauna was likely small (FR $<<$ DOU), whereas no large bio-irrigators species were recorded in the faunal analysis, and so oxygen uptake by bio-irrigation was likely unimportant (IOU $<<$ DOU). Overall, the contribution of fauna to the sedimentary oxygen uptake within sediments below $15 \mathrm{~m}$ water depth cannot be substantial, and hence, seasonality in macrofaunal activity does not seem to strongly affect the TOU.

Moreover, a substantial faunal imprint would create a discrepancy between DOU and TOU (Wenzhöfer and Glud 2002; Glud 2008), which was not observed (Fig. 5). Even in late spring, when faunal densities were the highest, DOU and TOU were similar. In general, the TOU and DOU followed a similar seasonal pattern and were not significantly different from each other (Fig. 5), suggesting a low bioirrigation activity of the benthic community (Rabouille et al. 2003). One notable exception was the period from September to October at Sta. S1 (DOU/TOU ratio $\sim 0.6$ ). These low DOU/TOU ratios coincided with the presence of Beggiaotaceae mats on the sediment surface, that is, large filamentous sulfur oxidizing bacteria, that were extensively present from September to November (Seitaj et al. 2015). The surface mats of Beggiaotaceae filaments alter the sediment microtopography, and as a consequence they affect the thickness of the DBL and increase the overall area of the sediment-water interface (Jørgensen and Des Marais 2008). A higher surface area leads to an increase of the oxygen flux across the sediment-water interface (detected via the TOU measurement) which is not captured in the one-dimensional flux calculated from the oxygen depth profiles (DOU) (Jørgensen and Des Marais 2008). As DOU values were calculated from concentration gradients inside the sediment, any $\mathrm{O}_{2}$ consumption 
by Beggiaotaceae above the sediment-water interface would lead to a difference between TOU and DOU. Accordingly, this mechanism could explain the low DOU/TOU ratio observed at S1 in the fall of 2012.

\section{Contribution of reoxidation to sedimentary oxygen consumption}

The sedimentary oxygen dynamic in Lake Grevelingen is driven by two main types of oxygen consumption: aerobic respiration of organic matter vs. reoxidation of reduced compounds. To assess the relative contribution of these two mechanisms, we performed a model analysis of the oxygen depth profiles recorded by micro-sensor profiling. The shape of the oxygen depth profile, and also the OPD, is determined by the actual location where oxygen consumption takes place within sediment. Effectively, one can think of two end-member models (corresponding expressions for the $\mathrm{O}_{2}$ depth profile and the OPD are provided in Methods section Fig. $8 \mathrm{a}, \mathrm{b}$ ). In a first model, the $\mathrm{O}_{2}$ consumption is uniformly distributed throughout the oxic zone (Bouldin 1968; Cai and Sayles 1996). This situation is expected when heterotrophic respiration of organic matter is the dominant $\mathrm{O}_{2}$ consuming process. As the oxic zone is narrow, likely the reactivity of organic matter does not vary with depth, and so to a first approximation, the rate of aerobic respiration can be assumed to remain constant with depth. In a second model, all the $\mathrm{O}_{2}$ consumption is concentrated near the OPD (Meysman et al. 2010). This situation is expected when reoxidation of reduced mineralization products (e.g., oxidation of ammonium or free sulfide) is the dominant $\mathrm{O}_{2}$ consuming process. Typically, reoxidation reactions have fast kinetics and are concentrated in a narrow zone around the oxicanoxic transition depth. In this reoxidation end-member model, the $\mathrm{O}_{2}$ depth profile becomes a straight line down to the OPD.

As illustrated for two representative examples (Fig. 8 a,b), the observed $\mathrm{O}_{2}$ depth profiles resided typically in between the depth profiles predicted by the two end-member models. The observed depth profiles showed more curvature than the $100 \%$ reoxidation model, but were also more linear than the $100 \%$ aerobic respiration model, implying that the observed $\mathrm{O}_{2}$ consumption was a mix of these two $\mathrm{O}_{2}$ consumption modes. The intensification of the $\mathrm{O}_{2}$ consumption near the oxic-anoxic transition causes a straightening of the concentration depth profile and a reduction in the OPD (Fig. 8 a,b).

Figure 8c plots the OPD vs. the DOU for all sampling dates and stations, and adds the two model predictions (using an average porosity $\varphi=0.95$ and mean bottom water concentration across all stations $\left[\mathrm{O}_{2}\right]_{\mathrm{bw}}=223.8 \mu \mathrm{mol} \mathrm{L} \mathrm{L}^{-1}$ ). The data show an inverse relation between OPD and DOU, as has been noted in previous investigations (Cai and Sayles 1996; Glud 2008; Glud et al. 2009). Most data points fall in between the two end-member model curves (Fig. 8c), although there is a tendency toward the $100 \%$ reoxidation model line, suggesting that reoxidation is a larger component of the $\mathrm{O}_{2}$ consumption, compared to aerobic respiration. Accordingly, we conclude that under oxic bottom water conditions, reoxidation of secondary metabolites is the principal driver of benthic oxygen consumption in the sediments of Lake Grevelingen below $15 \mathrm{~m}$ water depth. This is not unexpected for these organic-rich sediments, which support high rates of anaerobic mineralization, and thus sustain high rates of reoxidation (Seitaj et al. 2015). Note that some points fall below the $100 \%$ reoxidation model line. These points were recorded during the stratification period in late spring, when the bottom water oxygen was low (and hence lower than the yearly averaged bottom water $\left[\mathrm{O}_{2}\right]_{\mathrm{bw}}$ used in the calculation of the model predictions).

\section{Bottom water $\mathrm{O}_{2}$ concentrations control TOU}

At the deepest station (S1), we observed a strong seasonal fluctuation in the TOU (an excursion of around 68 mmol $\mathrm{O}_{2} \mathrm{~m}^{-2} \mathrm{~d}^{-1}$ between maximum and minimum TOU). A similar excursion was observed also in the DOU, where the highest DOU recorded ( $58 \mathrm{mmol} \mathrm{m}^{-2} \mathrm{~d}^{-1}$ in Nov 2012) is 3.4 times higher than the lowest DOU recorded during oxic conditions (17 mmol m $\mathrm{m}^{-2} \mathrm{~d}^{-1}$ in Feb 2012). However, pronounced variations in the sedimentary oxygen uptake were not observed at shallower water depths. In contrast with S1, Sta. S2 showed a seasonal cycle with lower amplitude, while S3 showed no seasonality at all. The absence of a clear seasonal pattern in the TOU and DOU recorded at Sta. S2 and S3 (Fig. 5b,c) speaks against a major influence of temperature. Overall, the TOU showed no significant correlation with bottom water temperature $\left(R^{2}=0.001 ; p=0.83\right.$ Fig. $\left.8 \mathrm{~d}\right)$, suggesting that temperature is not a major driver of the observed seasonal variation in sedimentary oxygen uptake in the Lake Grevelingen.

Water column oxygenation, and more specifically oxygen limitation, is another factor that may affect sedimentary oxygen uptake. Prolonged chamber incubations have given insight into the relation between sedimentary oxygen consumption rate and oxygen concentration in the enclosed bottom water (Hall et al. 1989; Glud 2008). During the initial phase of an incubation, the oxygen decrease in the water overlying the sediment is approximately linear over time (Glud 2008), indicating that the consumption rate does not depend on the oxygen availability. However, when the oxygen concentrations in the water passes the hypoxia threshold, this relation becomes non-linear, as the oxygen uptake slows down at decreased $\mathrm{O}_{2}$ levels (Glud 2008). This might explain why the sediment oxygen consumption is usually depressed under hypoxic to anoxic conditions in systems such as Chesapeake Bay (Boynton et al. 1990; Brady et al. 2013) and the Louisiana continental shelf (Rowe et al. 2002; Lehrter et al. 2011). Similarly, at the field site here, the TOU was reduced by oxygen availability in early summer at Sta. S1 and S2 (Fig. 5) but not at Sta. S3 (which remained above 


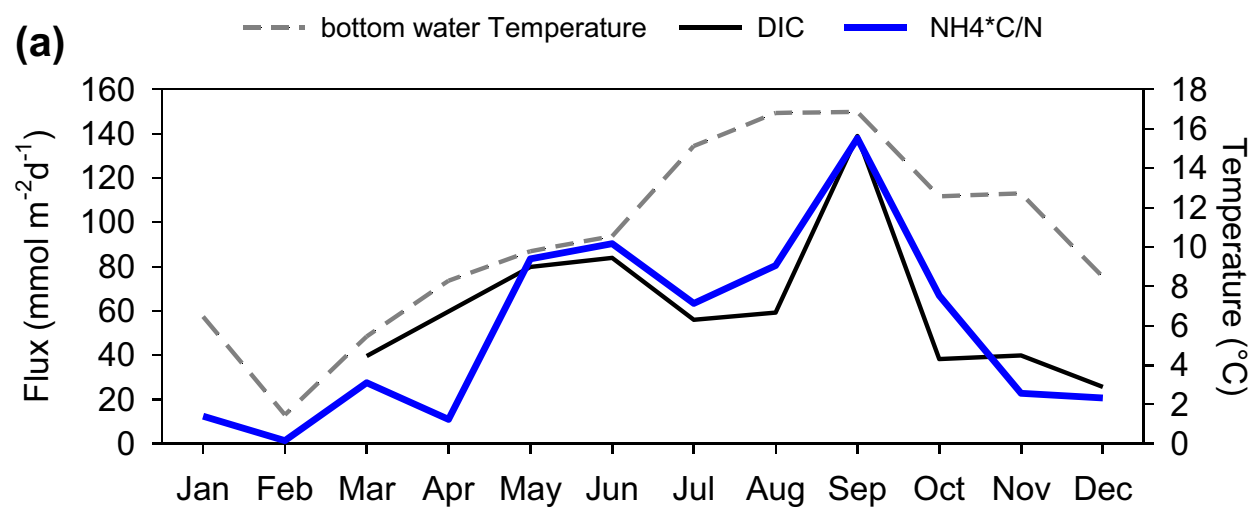

(b) $\quad$ expected TOU $\quad$ observed TOU

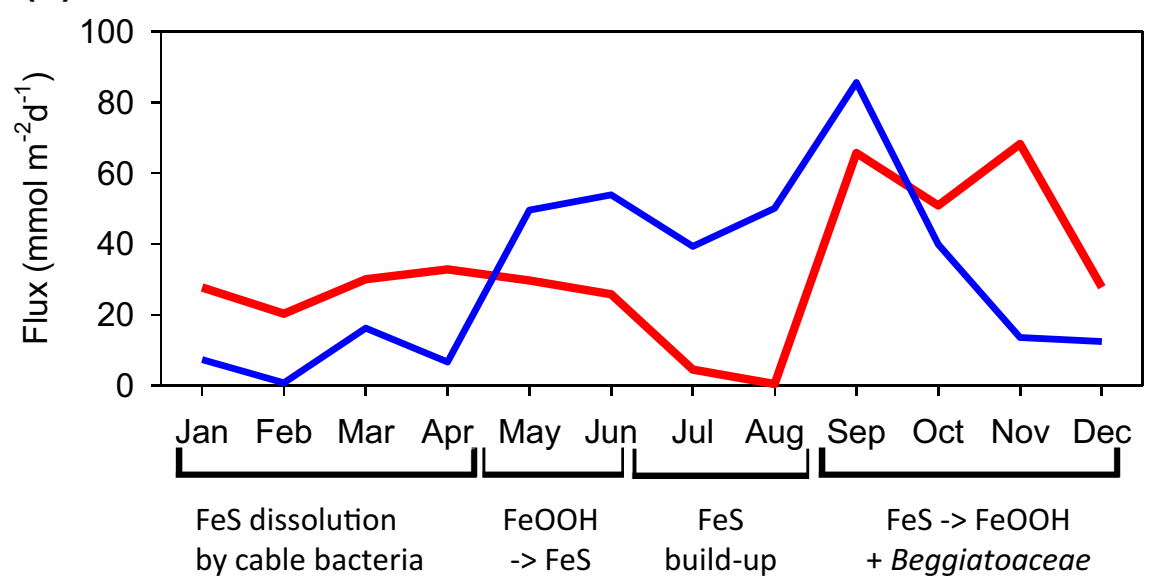

Fig. 9. (a) Bottom water temperature, benthic DIC efflux and $\mathrm{NH}_{4}^{+}$-based mineralization at $\mathrm{S} 1$ throughout 2012. (b) Seasonal variation of "expected" vs. "observed" TOU at S1. The "expected TOU" was calculated from the $\mathrm{NH}_{4}^{+}$-based mineralization divided by the mean annual respiratory quotient (RQ), whereas the "observed TOU" is the measured TOU. During January-April, the sedimentary oxygen consumption was affected by oxidation of FeS promoted by cable bacteria metabolism; during spring and summer, accumulation of FeS occurs; from September onwards Beggiatoaceae affect sedimentary oxygen consumption.

the hypoxia threshold). Hence, we conclude that bottom water oxygen availability exerted the dominant control on the TOU in summer in the deeper basins of Lake Grevelingen.

\section{The importance of the oxygen debt mechanism}

Among the three sites investigated, the deepest site (S1) experiences the longest and most intense period of hypoxia, and so its response most strongly exemplifies the impact of seasonal hypoxia on sediment oxygen dynamics. To analyze this seasonality, Fig. 9b compares the seasonal patterns of the "expected TOU" vs. the "observed TOU."

The "expected TOU" is the sedimentary oxygen consumption that is expected if mineralization of organic matter is the sole, instantaneous driver of the oxygen consumption. This model hence assumes that the TOU always linearly scales with the mineralization rate. To calculate the "expected TOU," we divided the monthly values of the $\mathrm{NH}_{4}^{+}$ flux- based mineralization rate by the mean annual respiratory quotient RQ (blue curve; Fig. 9b). The "observed TOU" simply represents the measured TOU values at S1 (red curve; Fig. 9b).

There are clear discrepancies between the "expected" and "observed" TOU, and we hypothesize that these differences can be largely explained by the concept of the so-called "sedimentary oxygen debt" (Pamatmat 1971). In coastal sediments, the mineralization of organic matter is dominated by anaerobic pathways, which lead to the accumulation of reduced by-products (i.e., $\mathrm{NH}_{4}^{+}, \mathrm{H}_{2} \mathrm{~S}$, and $\mathrm{FeS}$ ) that can be viewed as ODUs (Soetaert et al. 1996). On transport to the sediment-water interface, these ODUs come into contact with $\mathrm{O}_{2}$, and are re-oxidized again. In a balanced sedimentary system, the production of ODUs through mineralization is exactly matched by the consumption of ODUs through reoxidation. In this situation, the seasonal oxygen uptake of the sediment would closely track the seasonal pattern in 
sedimentary mineralization (i.e., the "observed" TOU tracks the "expected" TOU). However, when reduced compounds (e.g., ODUs like FeS) are not immediately re-oxidized and transiently accumulate in the sediment, the oxygen consumption becomes out of phase with the mineralization. Under these conditions, the TOU is temporarily lower than expected from the ongoing mineralization (creation of the oxygen debt). Later in the seasonal cycle, the reverse situation can occur, when the pool of reduced compounds is reoxidized, and the TOU is higher than required by the ongoing mineralization (fulfilment of the oxygen debt). An increased TOU compared to mineralization in fall, associated with the fulfilment of an "oxygen debt," has been previously reported in geochemical studies of seasonally-hypoxic sites, including Aarhus Bay (Rasmussen and Jorgensen 1992; Moeslund et al. 1994), Cape Lookout Bight (Martens and Klump 1984; Chanton et al. 1987), and Chesapeake Bay (Boynton et al. 1990; Brady et al. 2013).

Seasonal hypoxia within the Den Osse basin induces a strong oxygen debt dynamic in the sediments at S1, with oscillations between periods of oxygen debt fulfilment and periods of oxygen debt creation (Fig. 9b). Here, we put forward the hypothesis that the oxygen debt dynamic is closely linked to the activity of cable bacteria, which enable electrogenic sulfur oxidation via electrical currents (Nielsen et al. 2010; Pfeffer et al. 2012). As described in detail in Seitaj et al. (2015), these cable bacteria are abundant and active in spring at S1, and their presence exerts a strong impact on the seasonality of the sediment geochemistry. The sedimentary iron and sulfur cycling in the sediments at S1 is described in detail in Seitaj et al. (2015) and Sulu-Gambari et al. (2016), and taking advantage of this dataset, it is possible to distinguish four distinct periods in terms of sedimentary $\mathrm{O}_{2}$ cycling over 2012 (Fig. 9b). At the beginning of the year, from January to April, electrogenic sulfur oxidation by cable bacteria generated a large pool of iron (hydr)oxides (950 $\mathrm{Fe} \mathrm{mmol} \mathrm{m} \mathrm{m}^{-2}$ ) in the uppermost $3.5 \mathrm{~cm}$ of the sediment (Seitaj et al., 2015; SuluGambari et al., 2016), via the reoxidation of $\mathrm{FeS}$ to $\mathrm{FeOOH}$. The reoxidation of this FeS by oxygen $\left[\mathrm{FeS}+5 / 4 \mathrm{O}_{2}+3 / 2 \mathrm{H}_{2} \mathrm{O}\right.$ $\rightarrow \mathrm{FeOOH}+\mathrm{SO}_{4}^{2-}+2 \mathrm{H}^{+}$; (Meysman et al. 2015)] would induce an extra $\mathrm{O}_{2}$ consumption of $1188 \mathrm{mmol} \mathrm{O}_{2} \mathrm{~m}^{-2}$, corresponding to an additional oxygen consumption of $\sim 9$ mmol $\mathrm{O}_{2} \mathrm{~m}^{-2} \mathrm{~d}^{-1}$ (assuming cable bacteria are active over a period of $130 \mathrm{~d}$ ). This way, the metabolic activity of cable bacteria in spring induces a period of "oxygen debt fulfilment" (Fig. 8b), which increases the sedimentary $\mathrm{O}_{2}$ consumption in winter and spring above the level expected from mineralization alone (from $13 \mathrm{mmol} \mathrm{O} \mathrm{m}^{-2} \mathrm{~d}^{-1}$ expected to $21 \mathrm{mmol} \mathrm{O}_{2} \mathrm{~m}^{-2} \mathrm{~d}^{-1}$ observed, where the latter is the observed average DOU at S1 over January-May).

From May onwards, the iron (hydr)oxides formed during spring, become reduced and precipitate as iron sulfides on contact with free sulfide (Seitaj et al. 2015; Sulu-Gambari et al. 2016) as described by the overall reaction $8 \mathrm{FeOOH}+$
$9 \mathrm{HS}^{-}+7 \mathrm{H}^{+} \rightarrow 8 \mathrm{FeS}+\mathrm{SO}_{4}^{2-}+12 \mathrm{H}_{2} \mathrm{O}$. This process hence creates two consecutive periods of oxygen debt. In a first period, the iron oxides formed close to the sediment surface could be mixed downwards into deeper sulfidic horizons (1 to $2 \mathrm{~cm}$ ) by small bioturbating fauna, which attained the highest abundances in May and June (Fig. 4). This FeOOH to FeS transformation continued-and most likely accelerated-throughout summer, when the bottom water oxygen decreased toward anoxia (Fig. 2c), and free sulfide accumulated to high levels in the upper sediment layers (Seitaj et al. 2015).

In principle, the seasonal oxygen debt dynamics should also induce a seasonality in the alkalinity within the sediment. Iron sulfide oxidation is associated with alkalinity consumption, and hence, an input of alkalinity to the sediment is expected in spring. Conversely, iron and sulfate reduction coupled to the subsequent burial of iron sulfide minerals such as iron monosulfide $(\mathrm{FeS})$ and pyrite $\left(\mathrm{FeS}_{2}\right)$ (Stumm and Morgan 1996) is accompanied by alkalinity production, and hence, alkalinity is expected to be released from the sediment during summer. However, the TA flux data show actually the opposite pattern. The largest TA efflux is observed in spring, especially at S1, while in contrast, the sediment shows a small TA influx in fall (Fig. 6c). This discrepancy can be explained by the observation that cable bacteria were active at S1 in spring (Seitaj et al. 2015) and the metabolism of these bacteria (electrogenic sulfur oxidation) is known to acidify the first centimeters of the sediment. This acidification induces carbonate dissolution (Risgaard-Petersen et al. 2012), which produces alkalinity and hence masks the alkalinity consumption by FeS oxidation, thus explaining the net alkalinity flux out of the sediment (Rao et al. 2016).

In fall, when bottom waters become oxygenated again, another period of oxygen debt fulfilment was started. At this time, Beggiaotaceae filaments colonized the sediment, but in contrast to cable bacteria, the Beggiatoaceae do not directly affect the FeS pool in the sediment. Hence, during this period, the FeS in the surface layer will be re-oxidized only by $\mathrm{O}_{2}$ diffusing into the sediment. Adopting an OPD of $2 \mathrm{~mm}$, the transient reoxidation of all FeS in contact with oxygen

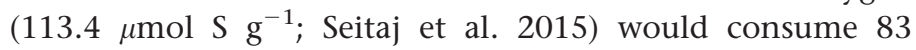
mmol $\mathrm{O}_{2} \mathrm{~m}^{-2}$. Assuming this $\mathrm{FeS}$ reoxidation takes place within $60 \mathrm{~d}$, this would only increase the sedimentary oxygen uptake by $1.4 \mathrm{mmol} \mathrm{O}_{2} \mathrm{~m}^{-2} \mathrm{~d}^{-1}$. However, substantially larger increases in the TOU are observed in fall, which could be due to high sulfate reduction rates associated with an increased temperature of the bottom water and sediment in fall (Fig. 2A). But it is also possible that the intensity of the oxygen debt fulfilment is higher, as for example, due to resuspension effects on TOU. During core inspection, we observed oxidized sediment patches within the surface layer of the sediment (up to $0.5 \mathrm{~cm}$; Fig. 3d), which might have resettled after being resuspended and oxidized in contact with oxygen. We do not have observational data to quantify the importance of resuspension at the field site. It is, 
however, possible that strong winds and stormy conditions, which typically occur in late fall and winter, may cause the resuspension of the fluffy surface sediments present at the study site. This mixing by resuspension might bring anoxic sediment to the sediment surface, where it is exposed to oxic bottom water. In the eventuality that the upper $1.5 \mathrm{~cm}$ of sediment would be mixed by resuspension, and the entire FeS pool contained in this layer $\left(49 \mu \mathrm{mol} \mathrm{S} \mathrm{cm}{ }^{-2}\right.$ ) would be re-oxidized in $60 \mathrm{~d}$, this would add $\sim 10 \mathrm{mmol} \mathrm{O}_{2} \mathrm{~m}^{-2} \mathrm{~d}^{-1}$ to the TOU. It must be noted that the oxidation of $\mathrm{NH}_{4}^{+}$released from the sediment to the bottom water in fall could additionally contribute to the observed high TOU rates.

These nitrate-accumulating Beggiatoaceae generate alkaline conditions in the surface sediment, thus favoring carbonate precipitation and alkalinity consumption, which explain the observed influx of alkalinity in the fall (Fig. 6c).

The high TOU in winter, and the absence of a clear response of TOU to bottom water temperature, were also observed in S2 and S3. Still, the seasonal pattern of oxygen debt dynamic was not as clear as at S2 and S3, possibly due to the lower intensity of hypoxia compared to S1. Especially at Sta. S3 (17 m water depth), summer hypoxia is less intense compared to S1 (Fig. 2c), and so reduced compounds accumulate to lower concentrations in the surface sediment (Sulu-Gambari et al. 2016). Hence, these layers form a lower oxygen debt during summer, which could explain why the TOU increases less in fall (Fig. 5b,c). Station 2 is influenced more by oxygen limitation in summer (although still less than S1), but as argued above, the oxygen debt dynamics is particularly amplified by the activity of cable bacteria in spring. Cable bacteria have a patchy distribution in the Lake Grevelingen (Seitaj et al., 2015), and were not detected at S2 in spring 2012, which could explain the less pronounced fluctuations of the TOU and DOU throughout 2012 at this station. Overall, based on our results, we forward the hypothesis that cable bacteria could substantially amplify the oxygen debt dynamics in the sediments of seasonal hypoxic coastal systems, but the extent to which this occurs requires more detailed quantification, as well as confirmation in coastal systems other than Lake Grevelingen.

\section{References}

Aller, R. C. 1988. Benthic fauna and biogeochemical processes in marine sediments, p. 301-338. In T. H. Blackburn and J. Sorensen [eds.], Nitrogen cycling in coastal marine environments. Wiley.

Archer, D., and A. Devol. 1992. Benthic oxygen fluxes on the Washington shelf and slope: A comparison of in situ microelectrode and chamber flux measurements. Limnol. Oceanogr. 37: 614-629. doi:10.4319/lo.1992. 37.3.0614

Banta, G., M. Holmer, M. Jensen, and E. Kristensen. 1999. Effects of two polychaete worms, Nereis diversicolor and Arenicola marina, on aerobic and anaerobic decomposition in a sandy marine sediment. Aquat. Microb. Ecol. 19: 189-204. doi:10.3354/ame019189

Berner, R. A. 1970. Sedimentary pyrite formation. Am. J. Sci. 268: 1-23. doi:10.2475/ajs.268.1.1

Berner, R. A., and J. T. Westrich. 1985. Bioturbation and the early diagenesis of carbon and sulfur. Am. J. Sci. 285: 193-206. doi:10.2475/ajs.285.3.193

Boudreau, B. P. 1996. The diffusive tortuosity of fine-grained unlithified sediments. Geochim. Cosmochim. Acta 60: 3139-3142.

Bouldin, D. R. 1968. Models for describing the diffusion of oxygen mud-water interface. J. Ecol. 56: 77-87. doi: $10.2307 / 2258068$

Boynton, W. R., W. M. Kemp, J. M. Barnes, J. L. W. Cowan, S. E. Stammerjohn, L. L. Matteson, F. M. Rohland, and M. Marvin. 1990. Long-term characteristics and trends of benthic oxygen and nutrient fluxes in the Maryland portion of Chesapeake Bay, p. 239-354. In J.H. Mihursky [eds.], New perspectives in the Chesapeake system: A research and management partnership. Chesapeake Research Consortium Publication.

Brady, D. C., J. M. Testa, D. M. Di Toro, W. R. Boynton, and W. M. Kemp. 2013. Sediment flux modeling: Calibration and application for coastal systems. Estuar. Coast. Shelf Sci. 117: 107-124. doi:10.1016/j.ecss.2012.11.003

Cai, W., and C. Reimers. 1995. Benthic oxygen flux, bottom water oxygen concentration and core top organic carbon content in the deep northeast Pacific Ocean. Deep-Sea Res. I 42: 1681-1699. doi:10.1016/0967-0637(95)00073-F

Cai, W. J., and F. L. Sayles. 1996. Oxygen penetration depths and fluxes in marine sediments. Mar. Chem. 52: 123-131. doi:10.1016/0304-4203(95)00081-X

Canfield, D. E. 1993. Organic matter oxidation in marine sediments, p. 333-363. In R. Wollast, F. T. Mackenzie, and L. Chou [eds.], Interactions of C, N, P, and S biogeochemical cycles and global change. Springer-Verlag, Berlin.

Canfield, D. E., and others. 1993. Pathways of organic carbon oxidation in three continental margin sediments. Mar. Geol. 113: 27-40. doi:10.1016/0025-3227(93)90147-N

Chanton, J. P., C. S. Martens, U. S. G. Survey, and M. B. Goldhaber. 1987. Biogeochemical cycling in an organicrich coastal marine basin. 7. Sulfur mass balance, oxygen uptake and sulfide retention. Geochim. Cosmochim. Acta 51: 1187-1199. doi:10.1016/0016-7037(87)90211-0

Conley, D. J., and others. 2009. Hypoxia-related processes in the Baltic Sea. Environ. Sci. Technol. 43: 3412-3420. doi: 10.1021/es802762a

Cook, P. L. M., D. P. Holland, and A. R. Longmore. 2010. Effect of a flood event on the dynamics of phytoplankton and biogeochemistry in a large temperate Australian lagoon. Limnol. Oceanogr. 55: 1123-1133. doi:10.4319/lo.2010.55.3.1123

Cornett, R. J., and F. H. Rigler. 1987. Decomposition of seston in the hyolimnion. Can. J. Fish. Aquat. Sci. 44: 146151. doi:10.1139/f87-019 
Diaz, R. J. 2001. Overview of hypoxia around the world. J. Environ. Qual. 30: 275-281. doi:10.2134/jeq2001.302275x

Diaz, R. J., and R. Rosenberg. 1995. Marine benthic hypoxia: A review of its icological effects and the behavioural responses of benthic macrofauna. Oceanogr. Mar. Biol. Annu. Rev. 33: 245-303.

Diaz, R. J., and R. Rosenberg. 2008. Spreading dead zones and consequences for marine ecosystems. Science 321: 926-929. doi:10.1126/science.1156401

Dickson, A. G., C. L. Sabine, and J. R. Christian. 2007. Guide to best practices for ocean CO2 15 measurements. PICES special publication, 3, North Pacific Marine Science Organization.

Donders, T. H., E. Guasti, F. P. M. Bunnik, and H. van Aken. 2012. Impact van de Brouwersdam op zuurstofcondities in de Grevelingen; reconstructies uit natuurlijke sediment archieven. TNO-report TNO-060-UT-2011-02116. Utrecht, Netherlands.

Feistel, R. 2008. A Gibbs function for seawater thermodynamics for -6 to $80^{\circ} \mathrm{C}$ and salinity up to $120 \mathrm{gkg}-1$. Deep-Sea Res. I 55: 1639-1671. doi:10.1016/j.dsr.2008. 07.004

Fenchel, T. 1996. Worm burrows and oxic microniches in marine sediments. 1. Spatial and temporal scales. Mar. Biol. 127: 289-295. doi:10.1007/BF00942114

Glud, R. N. 2008. Oxygen dynamics of marine sediments. Mar. Biol. Res. 4: 243-289. doi:10.1080/ 17451000801888726

Glud, R. N., and others. 2009. Nitrogen cycling in a deep ocean margin sediment (Sagami Bay, Japan). Limnol. Oceanogr. 54: 723-734. doi:10.4319/lo.2009.54.3.0723

Hagens, M., C. P. Slomp, F. J. R. Meysman, D. Seitaj, J. Harlay, A. V. Borges, and J. J. Middelburg. 2015. Biogeochemical processes and buffering capacity concurrently affect acidification in a seasonally hypoxic coastal marine basin. Biogeosciences 12: 1561-1583. doi:10.5194/bg-121561-2015

Hall, P. O. J., L. G. Onderson, M. M. R. Van Der Loeff, B. Sundby, and S. F. G. Westerlund. 1989. Oxygen uptake kinetics in the benthic boundary layer. Limnol. Oceanogr. 34: 734-746. doi:10.4319/1o.1989.34.4.0734

Holland, a. F., A. T. Shaughnessy, and M. H. Hiegel. 1987. Long-term variation in mesohaline Chesapeake Bay macrobenthos: Spatial and temporal patterns. Estuaries 10: 227-245. doi:10.2307/1351851

Jørgensen, B. B. 1977. The sulfur cycle of a coastal marine sediment (Limfjorden, Denmark). Limnol. Oceanogr. 22: 814-832. doi:10.4319/1o.1977.22.5.0814

Jørgensen, B. B. 1980. Seasonal oxygen depletion in the bottom waters of a Danish depletion and its effect on the benthic community. Oikos 34: 68-76. doi:10.2307/ 3544551

Jørgensen, B. B. 1996. Case study - Aarhus Bay, p. 137-154. In K. Richardson and B.B. Jørgensen [eds.], Eutrophication in coastal marine ecosystems. Coastal and estuarine studies. American Geophysical Union.

Jørgensen, B. B., and D. J. Des Marais. 2008. The diffusive boundary layer of sediments: Oxygen microgradients over a microbial mat. Limnol. Oceanogr. 35: 1343-1355. doi: 10.4319/lo.1990.35.6.1343

Kemp, W. M., and others. 2005. Eutrophication of Chesapeake Bay: Historical trends and ecological interactions. Mar. Ecol. Prog. Ser. 303: 1-29. doi:10.3354/ meps303001

Kemp, W. M., J. M. Testa, D. J. Conley, D. Gilbert, and J. D. Hagy. 2009. Temporal responses of coastal hypoxia to nutrient loading and physical controls. Biogeosciences $\mathbf{6}$ : 2985-3008. doi:10.5194/bg-6-2985-2009

Kristensen, E. 2000. Organic matter diagenesis at the oxic/ anoxic interface in coastal marine sediments, with emphasis on the role of burrowing animals. Hydrobiologia 426: 1-24. doi:10.1023/A:1003980226194

Kristensen, E. 2001. Impact of polychaetes (Nereis spp. and Arenicola marina) on carbon biogeochemistry in coastal marine sediments. Geochem. Trans. 2: 92. doi:10.1186/ 1467-4866-2-92

Lehrter, J. C., D. L. Beddick, R. Devereux, D. F. Yates, and M. C. Murrell. 2011. Sediment-water fluxes of dissolved inorganic carbon, O2, nutrients, and N2 from the hypoxic region of the Louisiana continental shelf. Biogeochemistry 109: 233-252. doi:10.1007/s10533-011-9623-X

Levin, L. A., and others. 2009. Effects of natural and humaninduced hypoxia on coastal benthos. Biogeosciences 6: 2063-2098. doi:10.5194/bg-6-2063-2009

Luther, G. W., A. Giblin, R. W. Howarth, and R. A. Ryans. 1982. Pyrite and oxidized iron mineral phases formed from pyrite oxidation in salt marsh and estuarine sediments. Geochim. Cosmochim. Acta 46: 2665-2669. doi: 10.1016/0016-7037(82)90385-4

Malkin, S. Y., A. M. Rao, D. Seitaj, D. Vasquez-Cardenas, E.M. Zetsche, S. Hidalgo-Martinez, H. T. Boschker, and F. J. Meysman. 2014. Natural occurrence of microbial sulphur oxidation by long-range electron transport in the seafloor. ISME J. 8: 1843-1854. doi:10.1038/ismej.2014.41

Martens, C. S., and J. Klump. 1984. Biogeochemical cycling in an organic-rich coastal marine basin 4. An organic carbon budget for sediments dominated by sulfate reduction and methanogenesis. Geochim. Cosmochim. Acta 48: 1987-2004. doi:10.1016/0016-7037(84)90380-6

McCave, I. N., R. J. Bryant, H. F. Cook, and C. A. Coughanowr. 1986. Evaluation of a Laser-Diffraction-Size Analyzer for Use with Natural Sediments. J. Sediment. Res. 56: 561-564. doi:10.1306/212F89CC-2B24-11D78648000102C1865D

Meire, L., K. E. R. Soetaert, and F. J. R. Meysman. 2013. Impact of global change on coastal oxygen dynamics and risk of hypoxia. Biogeosciences 10: 2633-2653. doi: 10.5194/bg-10-2633-2013 
Meysman, F. J. R., O. S. Galaktionov, R. N. Glud, and J. J. Middelburg. 2010. Oxygen penetration around burrows and roots in aquatic sediments. J. Mar. Res. 68: 309-336. doi:10.1357/002224010793721406

Meysman, F. J. R., N. Risgaard-Petersen, S. Y. Malkin, and L. P. Nielsen. 2015. The geochemical fingerprint of microbial longdistance electron transport in the seafloor. Geochim. Cosmochim. Acta 152: 122-142. doi:10.1016/j.gca.2014.12.014

Middelburg, J. J., and L. A. Levin. 2009. Coastal hypoxia and sediment biogeochemistry. Biogeosciences 6: 1273-1293. doi:10.5194/bg-6-1273-2009

Moeslund, L., B. Thamdrup, and B. B. Jørgensen. 1994. Sulfur and iron cycling in a coastal sediment: Radiotracer studies and seasonal dynamics. Biogeochemistry 27: 129152. doi:10.1007/BF00002815

Nielsen, L. P., N. Risgaard-Petersen, H. Fossing, P. B. Christensen, and M. Sayama. 2010. Electric currents couple spatially separated biogeochemical processes in marine sediment. Nature 463: 1071-1074. doi:10.1038/ nature08790

Pace, M., and Y. Prairie. 2005. Respiration in lakes, p. 103121. In P. J. le. B. Williams and P. A. Del Giorgio [eds.], Respiration in aquatic ecosystems. Oxford Univ. Press.

Pamatmat, M. M. 1971. Oxygen consumption by the seabed. VI. Seasonal cycle of chemical oxidation and respiration in Puget Sound. Int. Rev. Hydrobiol. 56: 769-739. doi: 10.1002/iroh.19710560505

Pearson, T. H., and R. Rosenberg. 1978. Macrobenthic succession in relation to organic enrichment and pollution of the marine environment. Oceanogr. Mar. Biol. Annu. Rev. 16: 229-311.

Pfeffer, C., and others. 2012. Filamentous bacteria transport electrons over centimetre distances. Nature 491: 218-221. doi:10.1038/nature11586

Rabalais, N. N., R. E. Turner, and W. J. Wiseman. 2002. Gulf of Mexico Hypoxia, a.K.a. "the Dead Zone." Annu. Rev. Ecol. Syst. 33: 235-263. doi:10.1146/annurev.ecolsys.33. 010802.150513

Rabalais, N. N., R. J. Díaz, L. A. Levin, R. E. Turner, D. Gilbert, and J. Zhang. 2010. Dynamics and distribution of natural and human-caused hypoxia. Biogeosciences 7: 585-619. doi:10.5194/bg-7-585-2010

Rabouille, C., L. Denis, K. Dedieu, G. Stora, B. Lansard, and C. Grenz. 2003. Oxygen demand in coastal marine sediments: Comparing in situ microelectrodes and laboratory core incubations. J. Exp. Mar. Bio. Ecol. 285-286: 49-69. doi:10.1016/S0022-0981(02)00519-1

Rao, A. M. F., S. Y. Malkin, S. Hidalgo-Martinez, and F. J. R. Meysman. 2016. The impact of electrogenic sulfide oxidation on elemental cycling and solute fluxes in coastal sediment. Geochim. Cosmochim. Acta 172: 265-286. doi: 10.1016/j.gca.2015.09.014

Rasmussen, H., and B. B. Jorgensen. 1992. Microelectrode studies of seasonal oxygen uptake in a coastal sediment:
Role of molecular diffusion. Mar. Ecol. Prog. Ser. 81: 289303. doi:10.3354/meps081289

Risgaard-Petersen, N., A. Revil, P. Meister, and L. P. Nielsen. 2012. Sulfur, iron-, and calcium cycling associated with natural electric currents running through marine sediment. Geochim. Cosmochim. Acta 92: 1-13. doi:10.1016/j.gca.2012.05.036

Ritter, C., and P. A. Montagna. 1999. Seasonal hypoxia and models of benthic response in a Texas Bay. Estuaries 22: 7-20. doi:10.2307/1352922

Romero-Ramirez, A., A. Grémare, M. Desmalades, and J. C. Duchêne. 2013. Semi-automatic analysis and interpretation of sediment profile images. Environ. Model. Softw. 47: 42-54. doi:10.1016/j.envsoft.2013.04.008

Rosenberg, R., S. Agrenius, B. Hellman, H. C. Nilsson, and K. Norling. 2002. Recovery of marine benthic habitats and fauna in a Swedish fjord following improved oxygen conditions. Mar. Ecol. Prog. Ser. 234: 43-53. doi:10.3354/meps234043

Rowe, G. T., M. E. C. Kaegi, J. W. Morse, G. S. Boland, E. G. Escobar Briones, H. Heights, M. M. Service, and N. Orleans. 2002. Sediment community metabolism associated with continental shelf hypoxia, Northern Gulf of Mexico. Estuaries 25: 1097-1106. doi:10.1007/BF02692207

Seitaj, D., R. Schauer, F. Sulu-Gambari, S. Hidalgo-Martinez, S. Y. Malkin, L. D. W Burdorf, C. P. Slomp, and F. J. R. Meysman. 2015. Cable bacteria generate a firewall against euxinia in seasonally hypoxic basins. Proc. Natl. Acad. Sci. USA 112: 1327813283. doi:10.1073/pnas.1510152112

Simpson, J. H. 1981. The shelf-sea fronts: Implications of their existence and behaviour. Philos. Trans. R. Soc. A 302: 531-543. doi:10.1098/rsta.1981.0181

Soetaert, K., P. M. J. Herman, and J. J. Middelburg. 1996. Dynamic response of deep-sea sediments to seasonal variations: A model. Limnol. Oceanogr. 41: 1651-1668. doi: 10.4319/lo.1996.41.8.1651

Soetaert, K., and J. J. Middelburg. 2009. Modeling eutrophication and oligotrophication of shallow-water marine systems: The importance of sediments under stratified and well-mixed conditions. Hydrobiologia 629: 239-254. doi: 10.1007/s10750-009-9777-x

Soetaert, K., T. Petzoldt, and F. J. R. Meysman. 2010. MARELAC: tools for aquatic science. $\mathrm{R}$ package version 2.1.2 Software.

Steckbauer, A., C. M. Duarte, J. Carstensen, R. Vaquer-Sunyer, and D. J. Conley. 2011. Ecosystem impacts of hypoxia: Thresholds of hypoxia and pathways to recovery. Environ. Res. Lett. 6: 025003. doi:10.1088/1748-9326/6/2/025003

Stumm, W., and J. J. Morgan. 1996. Aquatic chemistry: Chemical equilibria and rates in natural waters, 3rd ed. John Wiley and Sons, Inc., New York.

Sulu-Gambari, F., D. Seitaj, F. J. R. Meysman, R. Schauer, L. Polerecky, and C. P. Slomp. 2016. Cable bacteria control iron-phosphorus dynamics in sediments of a coastal hypoxic basin. Environ. Sci. Technol. 50: 227-1233. doi: 10.1021/acs.est.5b04369 
Testa, J. M., and W. M. Kemp. 2011. Oxygen - Dynamics and biogeochemical consequences, p. 163-200. In E. Wolanski and D. S. McLusky [eds.], Treatise on estuarine and coastal science. Academic Press.

Thamdrup, B., H. Fossing, and B. B. Jørgensen. 1994. Manganese, iron and sulfur cycling in a coastal marine sediment, Aarhus bay, Denmark. Geochim. Cosmochim. Acta 58: 5115-5129. doi:10.1016/0016-7037(94)90298-4

Thamdrup, B., J. Wu, and B. B. Jörgensen. 1998. Temperature dependence of aerobic respiration in a coastal sediment. FEMS Microbiol. Ecol. 25: 189-200. doi:10.1111/ j.1574-6941.1998.tb00472.x

Turner, R. E., N. N. Rabalais, and D. Justic. 2008. Gulf of Mexico hypoxia: Alternate states and a legacy. Environ. Sci. Technol. 42: 2323-2327. doi:10.1021/es071617k

Van Colen, C., F. Montserrat, M. Vincx, P. Herman, T. Ysebaert, and S. Degraer. 2008. Macrobenthic recovery from hypoxia in an estuarine tidal mudflat. Mar. Ecol. Prog. Ser. 372: 31-42. doi:10.3354/meps07640

Van Santvoort, P. J. M., G. J. De Lange, J. Thomson, S. Colley, F. J. R. Meysman, and C. P. Slomp. 2002. Oxidation and origin of organic matter in surficial Eastern Mediterranean hemipelagic sediments. Aquat. Geochem. 8: 153-175. doi:10.1023/A:1024271706896

Vaquer-Sunyer, R., and C. M. Duarte. 2008. Thresholds of hypoxia for marine biodiversity. Proc. Natl. Acad. Sci. USA 105: 15452-15457. doi:10.1073/pnas.0803833105
Wenzhöfer, F., and R. N. Glud. 2002. Benthic carbon mineralization in the Atlantic: A synthesis based on in situ data from the last decade. Deep-Sea Res. I 49: 1255-1279. doi: 10.1016/S0967-0637(02)00025-0

Wenzhöfer, F., and R. N. Glud. 2004. Small-scale spatial and temporal variability in coastal benthic O-2 dynamics: Effects of fauna activity. Limnol. Oceanogr. 49: 14711481. doi:10.4319/lo.2004.49.5.1471

Wetsteyn, L. P. M. J. 2011. Grevelingenmeer: Meer kwetsbaar? Lelystad, Netherlands.

\section{Acknowledgments}

We thank P. van Rijswijk, S. Hidalgo-Martinez, M. Hagens, A. Tramper, and the crew of the R/V Luctor (P. Coomans and M. Kristalijn) for their support during the Lake Grevelingen sampling campaigns. We are grateful to S. Hidalgo-Martinez for the macrofauna identification. This research was financially supported by the Darwin Center for Biogeosciences (D.S. and F.S.G.), and the European Research Council (ERC Grant 306933 to FJRM and ERC Grant 278364 to CPS).

\section{Conflict of Interest}

None declared.

Submitted 20 January 2016 Revised 24 May 2016 Accepted 20 June 2016

Associate editor: Ronnie Glud 